P.S.

Ro

682

no. 158

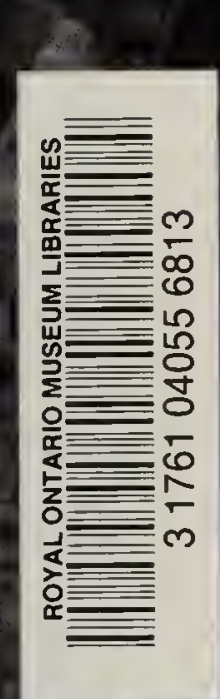

BREEDING-BIRD

POPULATIONS

IN JACK PINE AND

Mixed JACK PINE/

DeCiduOUS STANDS

in Central Ontario

Ross D. James and Mark K. Peck
ROYAL ONTARIO MUSEUM

LIFE SCIENCES CONTRIBUTIONS

158

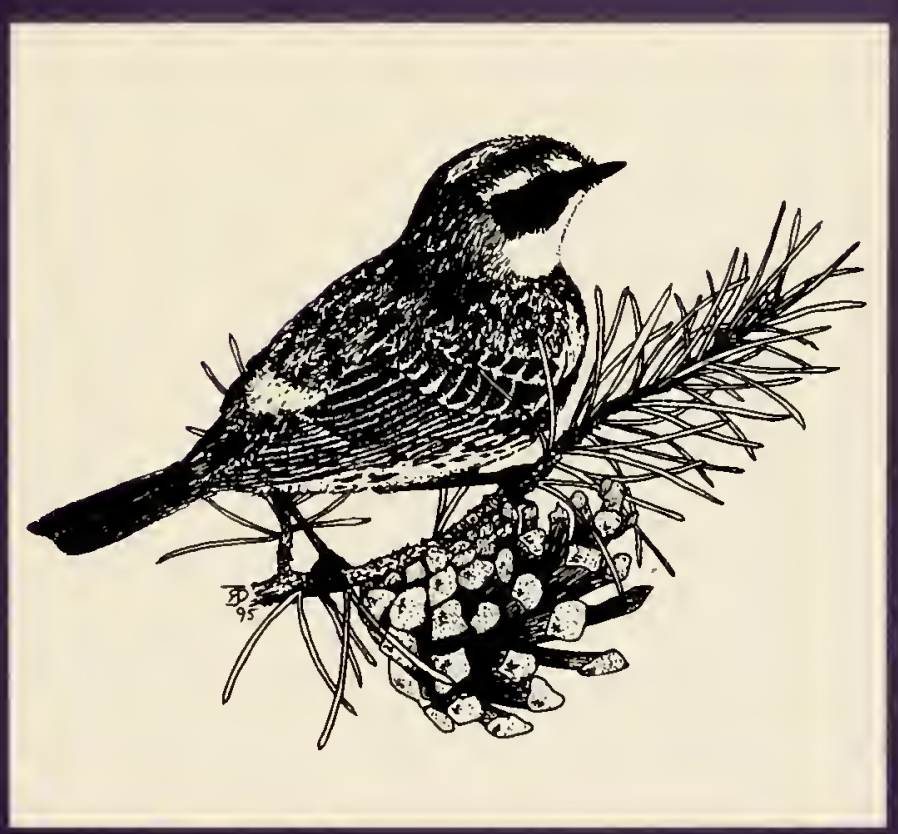

RO̊̊M 

BREEDING-BiRd Populations In JACK PINE AND MiXed JaCK PINE/DECIDUOUS STANDS IN CENTRAL ONTARIO 


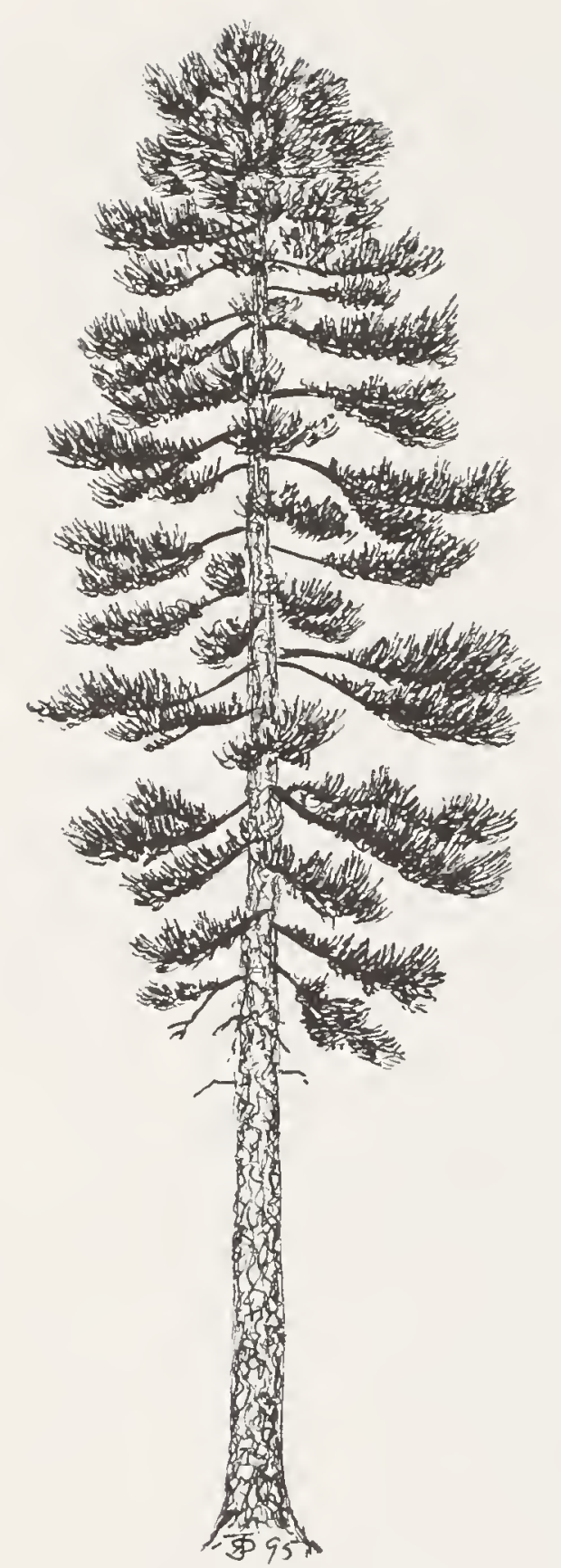

A mature jack pine (Pinus banksiana).

Illustration by Ross D. James. 
ROYAL ONTARIO MUSEUM

LIFE SCIENCES CONTRIBUTIONS

158

\section{BREEDing-Bird Populations In Jack Pine AND MiXed Jack Pine/Deciduous Stands IN CENTRAL ONTARIO}

Ross D. James

Mark K. Peck

\section{RO̊ $\mathrm{M}$}

ROYAL ONTARIO MUSEUM 
(C) 1995 Royal Ontario Museum

All rights reserved. No part of this publication may be reproduced, stored in a retrieval system or data base, or transmitted, in any form or by any means, electronic. mechanical, photocopying, or otherwise, without the prior written consent of the publisher.

First published in 1995 by the Royal Ontario Museum, 100 Queen's Park, Toronto, Ontario M5S 2C6.

Publication date: 1 May 1995

ISBN: 0-88854-413-8

ISSN: 0384-8159

\section{Canadian Cataloguing in Publication Data}

James, Ross D., 1943-

Breeding-bird populations in jack pine and mixed jack pine/deciduous stands in central Ontario

(Life sciences contributions; no. 158)

Includes bibliographical references.

ISBN 0-88854-413-8

1. Forest birds - Ontario. 2. Birds - Ontario.

3. Jack pine - Ontario. 4. Birds - Ecology -

Ontario. 5. Bird populations - Ontario.

6. Forest management - Ontario. I. Peck, Mark K.

(Mark Kelday) , 1959- . II. Royal Ontario

Museum. III. Title. IV. Series.

QL685.5.06J3 1995 598.29'152'09713 C95-930597-1

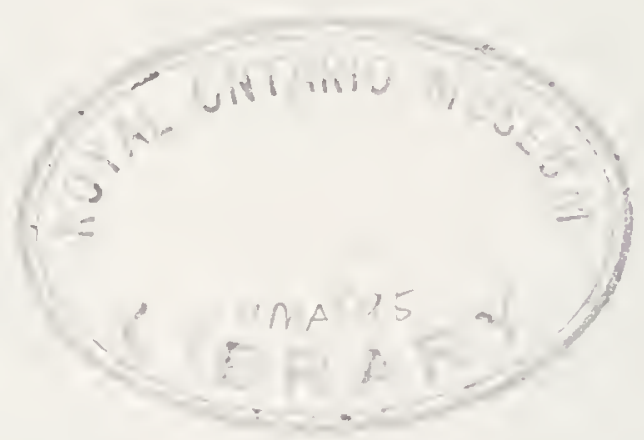

ROYAL ONTARIO MUSEUM PUBLICATIONS IN LIFE SCIENCES

The Royal Ontario Museum publishes books on a variety of subjects in the life sciences, including Life Sciences Contributions, a numbered series of original scientific publications. All manuscripts considered for publication are subject to the scrutiny and editorial policies of the Life Sciences Editorial Board, and to independent refereeing by two or more persons, other than Museum staff, who are authorities in the particular field involved.

\section{LIFE SCIENCES EDITORIAL BOARD}

Senior Editor: K. A. Coates

Editor: D. H. Collins

Editor: R. D. James

External Editor: C. S. Churcher

Manuscript Editor: K. A. Coates

Production Editor: Andrea Gallagher Ellis

Ross D. James is an associate curator in the Ornithology Department of the Royal Ontario Museum.

Mark K. Peck is a technician in the Ornithology Department of the Royal Ontario Museum.

The Royal Ontario Museum is an agency of the Ontario Ministry of Culture, Tourism and Recreation.

Cover: Yellow-rumped Warbler (Dendroica coronata) on a jack pine twig. Illustration by Ross D. James.

Printed and bound in Canada 


\section{Contents}

Abstract 1

Introduction 1

Methods 2

The Study Area 2

Habitat Data 8

Censuses 8

Results 10

Censuses 10

Species Accounts 18

Discussion 23

The Pine Forest 24

The Mixed Pine/Deciduous Forest 26

Pine Forest vs. Mixed Forest 26

Population Changes 27

Forestry 27

Conclusions 29

Acknowledgements 30

Literature Cited 31 
Digitized by the Internet Archive in 2011 with funding from Royal Ontario Museum 


\title{
Breeding-Bird Populations in Jack Pine and Mixed Jack Pine/Deciduous Stands in Central Ontario
}

\begin{abstract}
We studied breeding-bird populations between 1985 and 1992 in four different ages of managed jack pine stands, and three different ages of jack pines mixed with birch and aspen, in the Gogama area of central Ontario. We used variable-strip transect counts of at least $1 \mathrm{~km}$ in length to gather information on bird-species presence and abundance in different ages and compositions, and with supplementary observations we considered more specific habitat use by various species. This study also provided insight into how forestry practices may be affecting bird populations in these forests.

Very young stands attracted open-country and early-successional species typical of the area; only one of these species became part of the forest avifauna as stands matured. By 20 years of age pine stands had an assemblage of nine core species well established at maximum densities. These formed the dominant species at any age thereafter. Three additional species joined them as characteristic of those pine forests before 40 years of age. Other species were irregular and present only in small numbers except during outbreaks of budworm. Five of the core species appeared to be present in densities higher than expected in these managed, uniform-aged forests.

In contrast, in mixed forests at 20 years of age, many early-successional species persisted, and many more species associated with deciduous forests had moved in, as had many pine-dwelling species, so that population densities were overall at least double that of pine forests of comparable age. Most of the population was composed of deciduous-forest inhabitants; pine associates were comparatively few. As mixed forests matured to 40 years of age, early-successional species left and additional forestdwelling species appeared. Overall species diversity was somewhat higher than in pine forests, but overall abundance was about the same.

Managed, uniform-aged pine forests provided good habitat for a few species, and bird populations appeared to be about the same as those found in typical boreal spruce forests in Canada; however, the near-absence of cavity nesters suggested that forestry practices were having a detrimental impact on these species.
\end{abstract}

\section{Introduction}

In the Boreal Forest Region of Canada, jack pine (Pintus banksiana) is the only pine species that covers extensive areas (Moore, 1984). In Ontario it covers at least 15 per cent of the areas subject to tree harvest (the proportion is much higher in some parts) and is the second most important commercial tree species (Howse, 1984).
Jack pine tends to form large and relatively uniform stands, particularly on xeric sites, often after fires (Moore, 1984). In central Ontario, it occurs naturally over large districts (e.g., near Timmins, Kirkland Lake, Chapleau, and Gogama; Howse, 1984). As the demand for this tree continues to grow, it is increasingly planted in uniform- 
aged stands following clearcutting, and herbicide treatment contributes to the development of pure pine stands over extensive areas (Galloway, 1984).

Jack pine stands have received little study with respect to bird populations, perhaps because no boreal bird species rely solely on this habitat (Erskine, 1977), and populations have been regarded as impoverished variants of typical spruce-forest fauna (McLeod, 1967; Erskine, 1977). Knowing how many and which bird species are present in these managed forests is relevant to several questions about the potential effects of forest management on bird populations. But the few censuses that have been undertaken in boreal jack pine stands so far (McLeod, 1967; Erskine, 1977) do little more than provide a background for further studies. There has been increasing concern in recent years about widespread declines in bird populations, particularly of neotropical migrants, some of which summer in northern forests (Terborgh, 1989; Robbins, Dawson, and Dowell, 1989). We do not know whether forestry practices are negatively affecting breeding-bird populations, but if they are, they could also be contributing to an increase in the frequency and severity of insect outbreaks. Jack pine is subject to periodic infestations of jack pine budworm (Choris- toneura pinus), jack pine sawfly (Neodiprion swainei), and other insect pests (Howse, 1984), whose numbers can be influenced by bird populations (Holmes, Schultz, and Nothnagle, 1979; Mattson et al., 1968; Takekawa, Garton, and Langelier, 1982).

The present study had the following aims: 1) to gather information on bird-species presence and abundance in one boreal forest community type, jack pines, during the nesting season; 2) to see how bird-species composition and abundance changed with the age of the pines; 3 ) to see how bird-species composition and abundance was influenced by the presence of deciduous growth among the pines; and 4) to delineate more specific habitat use by birds in association with pine stands.

From this study we also hoped to gain insight into how forestry practices can be modified to benefit bird populations and thereby to take advantage of natural predators for insect control. The information we gathered addresses the general lack of bird-census data from boreal forest areas, and the detailed background information from this one area provides a basis of comparison that may some day allow researchers to assess a long-term trend in bird populations.

\section{Methods}

\section{THE STUDY AREA}

The study was conducted in central Ontario south of the town of Gogama, Sudbury District, mainly along Hwy 560 , east of its junction with Hwy $144\left(47^{\circ} 28^{\prime} \mathrm{N}, 81^{\circ} 51^{\prime}\right.$ W; Fig. 1). This area is within the Boreal Forest Region, a continuous belt of primarily coniferous forest found across most of the continent and comprising the greater part of the forested area of Canada (Rowe, 1959). More specifically it is the Missinaibi-Cabonga section which, although basically boreal insofar as the bulk of the tree species and their distributions are concerned, does contain species from the Great Lakes-St. Lawrence region, either as scattered individuals or as more or less isolated patches (Rowe, 1959).

The predominant forest of the Missinaibi-Cabonga section is mixed in character, consisting of an association of balsam fir, black spruce, and white birch, with scattered white spruce and trembling aspen (for plant names see Table 1). However, in this section extensive sand and gravel deposits provide a favourable environment for the prevalent jack pine. This section occupies the height of land between Hudson Bay and the Great Lakes. Its northern boundary coincides generally with the northernmost limits of white and red pine, yellow birch, and sugar maple (Rowe, 1959). Along Hwy 560, large areas of sandy soils together with other factors provide suitable conditions for jack pine, which is naturally occurring here. Areas readily accessible from the road now have plantations of jack pines of various ages where natural stands would otherwise be found.

Study efforts were concentrated in two broad categories of habitat: pine $(\mathrm{P})$ and mixed pine/deciduous $(\mathrm{M})$. In four pine habitats, jack pine was of a fairly uniform size and dispersion and very few trees of any other species were present. In three mixed habitats, jack pine was by far the dominant coniferous species and made up about half of all trees present. Deciduous trees were mainly trembling aspen and white birch. In the young mixed habitat (M-2, see below), tall deciduous shrubs in combination with deciduous trees exceeded pines in volume of foliage. However, in the medium-aged mixed stand (M-3, see below), pines and deciduous trees were about equal in numbers and habitat influence.

Censuses were obtained between 1985 and 1992 on seven different areas. Three pine stands of seven, 20, and 39 years of age when censusing began, followed through succeeding years, some for as long as eight years, gave a fairly detailed sequence of bird-community changes 
through the first half-century of the growth of these pine plantations. Likewise, three mixed stands of roughly corresponding ages outlined the sequence of changes there. A single older pine stand helped confirm that little change is expected in bird populations in plantations more than 50 years old unless the forest is not harvested until after trees reach maturity. The different areas are described below.

\section{P-1. New Growth of Pine (Fig. 2)}

A very young pine plantation $3 \mathrm{~km}$ west of the junction of Hwy 144 and Hwy 560 on the south side of the forestry road to Sultan, about $25 \mathrm{~km}$ southwest of Gogama (UTM squares 17MC3258, 3358, and 3357; map $41 \mathrm{P} / 5$, Invergarry Twp.).

Almost all growth above knee height here was small jack pines. This was a dry, flat, gravelly area in which pines were slow to grow. The pines seldom exceeded 1.5 $\mathrm{m}$ in height and were well spaced and fairly evenly distributed. The ground cover was largely sedges, blueberry bushes, and trailing arbutus, with a few clumps of Labrador tea and greenish mosses. A few snags persisted adjacent to the census area.

A census was carried out in 1985 when the trees were about seven years old. Some supplementary observations were made here in 1989 but no formal census was conducted.

\section{P-2. Young Pine (Fig. 3)}

A plantation of young pines, extending 0.5 to $5.5 \mathrm{~km}$ east of Hwy 144, on the north side of Hwy 560, about $23 \mathrm{~km}$ southwest of Gogama (UTM squares 17MC3758 and 3858; map 41 P/5, Vrooman Twp.).

This fairly uniform stand of jack pines was planted

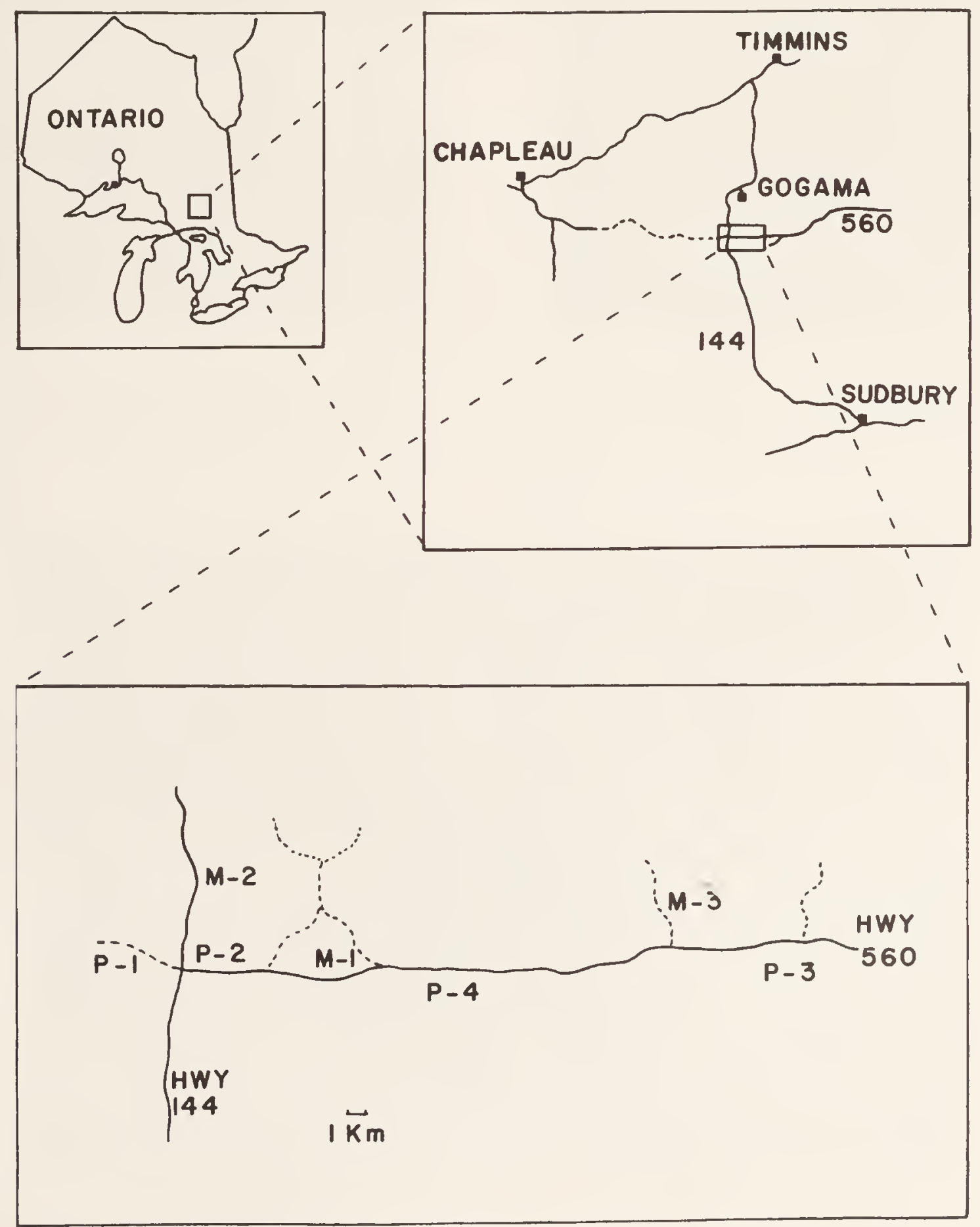

FIG. 1. Maps of the study area showing the location of the censused areas. 


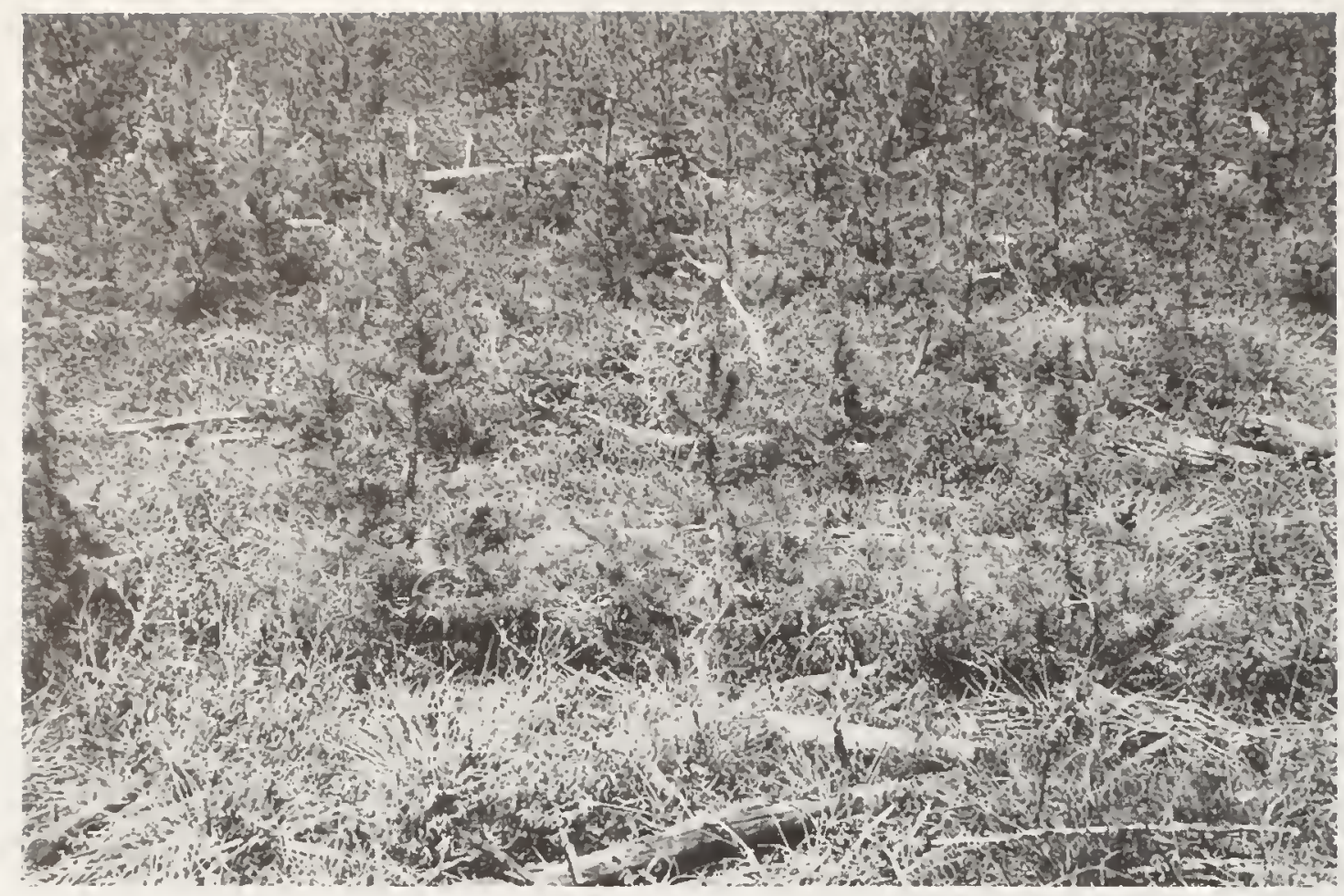

Fig. 2. New growth of pines (P-1); trees were about seven years old when the area was censused in 1985.

and/or aerially seeded and subsequently thinned to remove almost all trees but pines. A small number of trembling aspens persisted in a few tiny groves. One section of pines about $100 \mathrm{~m}$ wide was very dense because it was never thinned. A few white spruce, from seedlings to nearly the same height as the pines, persisted. No standing dead trees were present in this area. Tall shrubs (alder, willow, and pincherry) were thinly distributed throughout the area. The ground had a nearly complete cover of blueberry and sheep laurel as well as smaller herbaceous plants and moss. Sedges and some Labrador tea were found in a few places.

The ground was very level almost throughout. Censuses were conducted yearly from 1985 to 1991. The pines were about 20 years old in the first year of censusing. A number of nest boxes were placed in this habitat. These were readily accepted by Boreal Chickadee and no doubt contributed to the population.

\section{P-3. Medium-aged Pine (Fig. 4)}

A plantation of medium-aged pines on the south side of Hwy 560, about $25 \mathrm{~km}$ east of Hwy 144 and 27 to $28 \mathrm{~km}$ southeast of Gogama (UTM squares 17MC6057 and 6157; map 41 P/5, Garvey Twp.).

This area was almost pure jack pine, although a few white spruce trees were found. There were almost no dead trees standing in the entire area. Trees were relatively evenly spaced and provided ncarly complete canopy cover. Tall deciduous shrubs (alder and pincherry) were few to absent except for an occasional patch where they were numerous. The ground was covered almost completely with sheep laurel and blueberry bushes amongst which a variety of low herbaceous plants, lichens, and mosses could be found.

This area was nearly level. Censuses were carried out every year from 1985 to 1992 . The trees were about 39 years old when censusing began.

\section{P-4. Mature Pine (Fig. 5)}

A managed area of fairly uniformly spaced, older jack pines on the south side of Hwy 560, about $13 \mathrm{~km}$ east of Hwy 144 and 22 to $23 \mathrm{~km}$ south of Gogama (UTM squares 17MC4757 and 4756; map 41 P/5, Westbrook Twp.).

This area was almost pure jack pine with a few white spruce scattered throughout. Trees were more mature than in area P-3, and somewhat more widely spaced, but still relatively dense as is typical of a planted area. There was an almost complete absence of dead standing snags. Tall deciduous shrubs (pincherry and willow) were inconspicuous at best, but the ground was continuously covered with sheep laurel and blueberry bushes interspersed with low herbaceous plants, lichens, and mosses.

The ground was nearly level. Only one census was conducted here, in 1985, when trees were about 65 years old.

\section{M-1. New Growth of Mixed (Fig. 6)}

A burned area on the north side of Hwy 560 , about $9 \mathrm{~km}$ east of Hwy 144 and 21 to $22 \mathrm{~km}$ south of Gogama (on the east side of UTM square 17MC4458; map 4I P/5, Vrooman Twp.).

Fire swept through this area of about 100 ha in 1981. It was planted with jack pine secdlings in 1982 after most standing dead trees were mechanically flattened. A few 


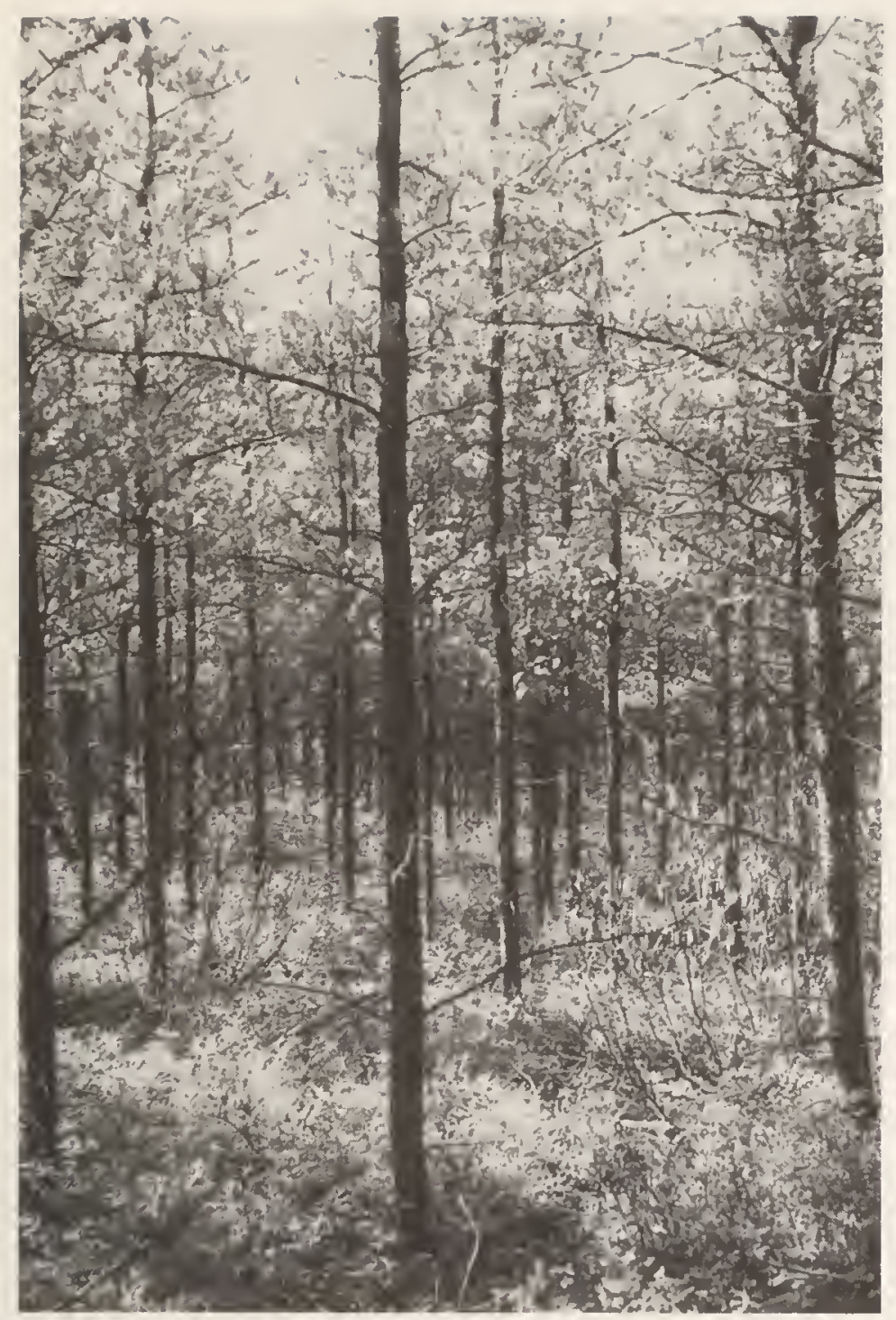

FIG. 3. Young pine plantation (P-2) censused from 1985 to 1991 when trees were about 20 to 26 years old. Photographed in 1985.

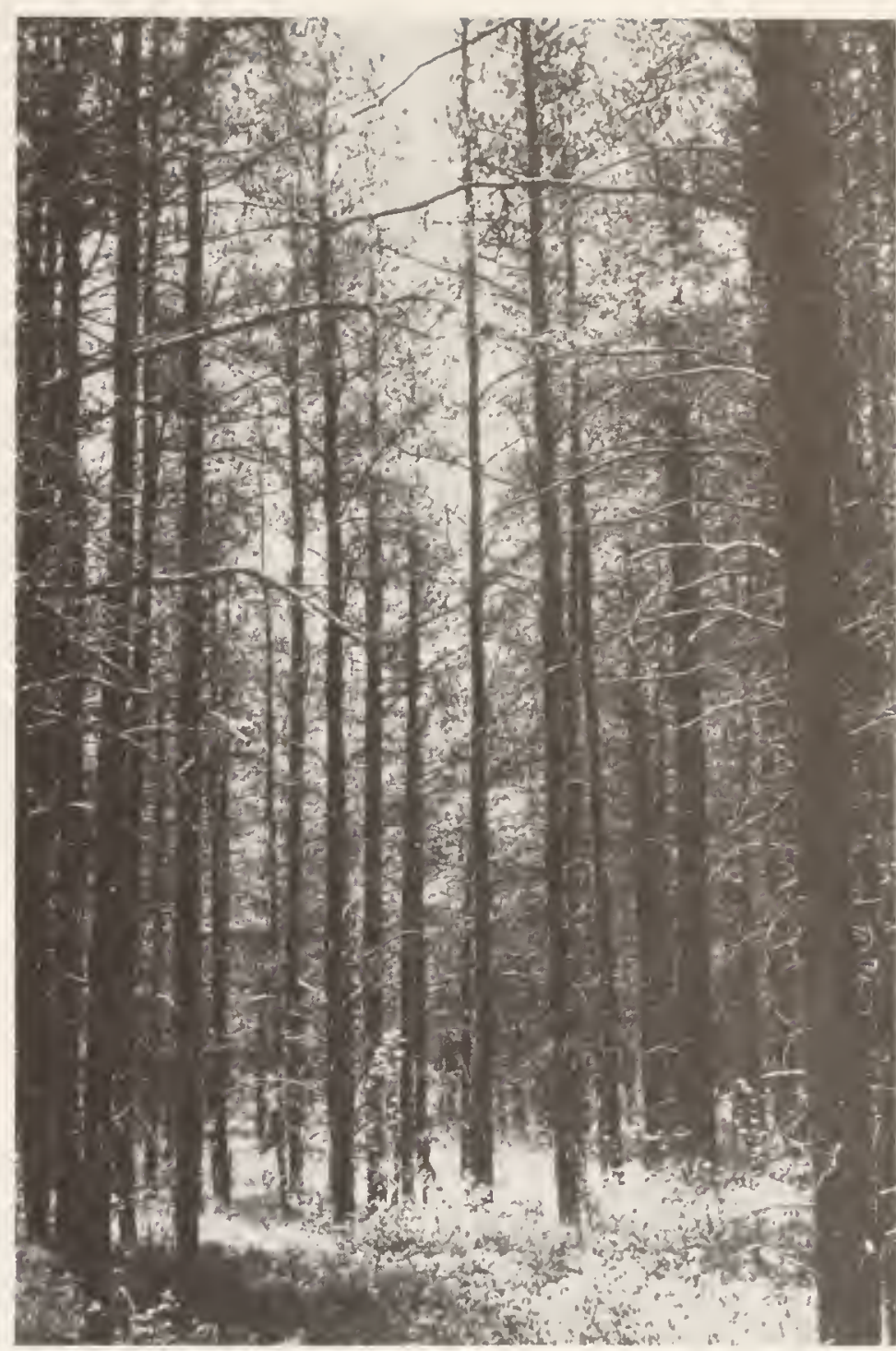

FIG. 4. Medium-aged pines (P-3) censused from 1985 to 1992 when trees were about 39 to 46 years old. Photographed in 1986.

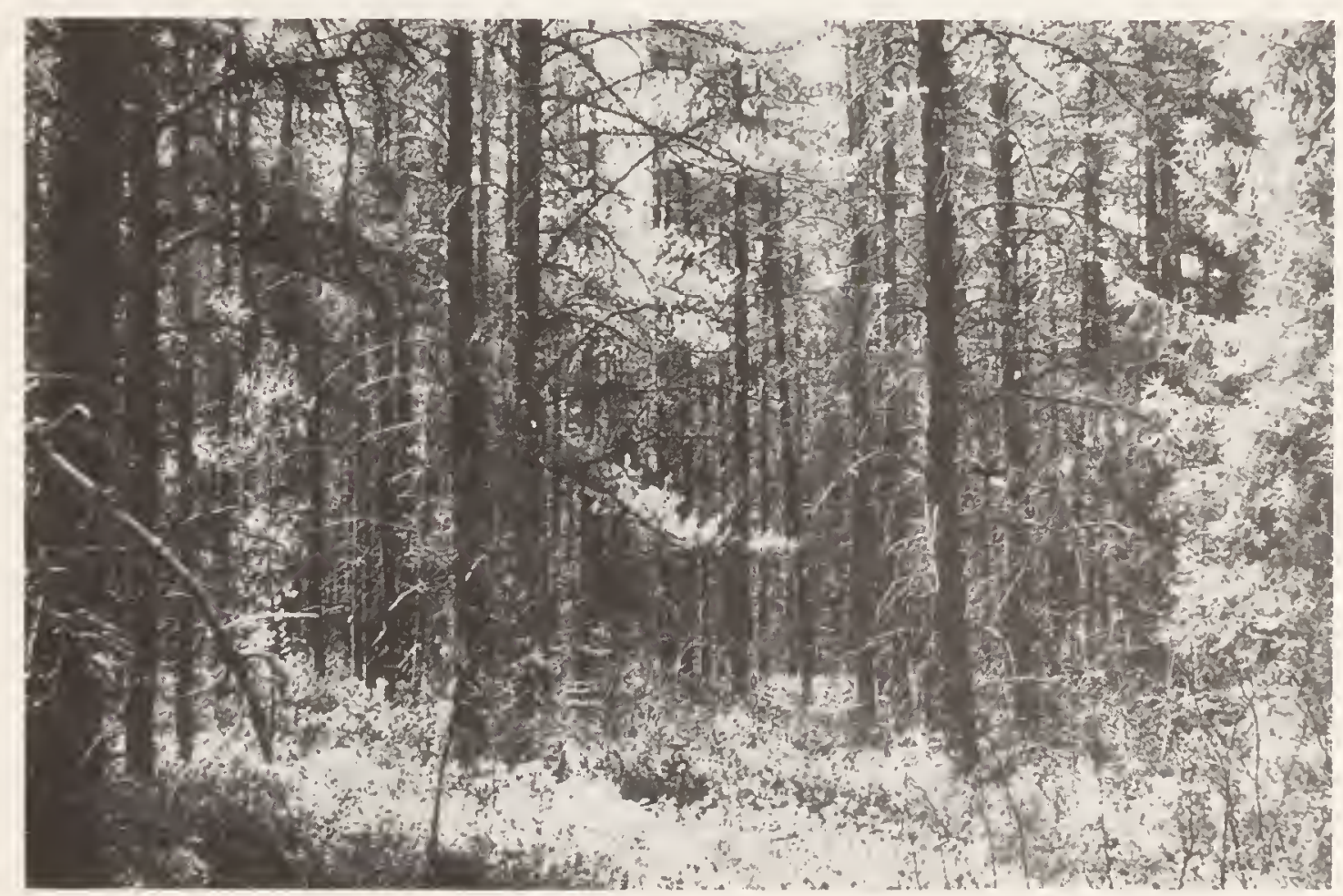

FIG. 5. Mature pine trees (P-4) censused in 1985 when trees were about 65 years old. Photographed in 1986. 


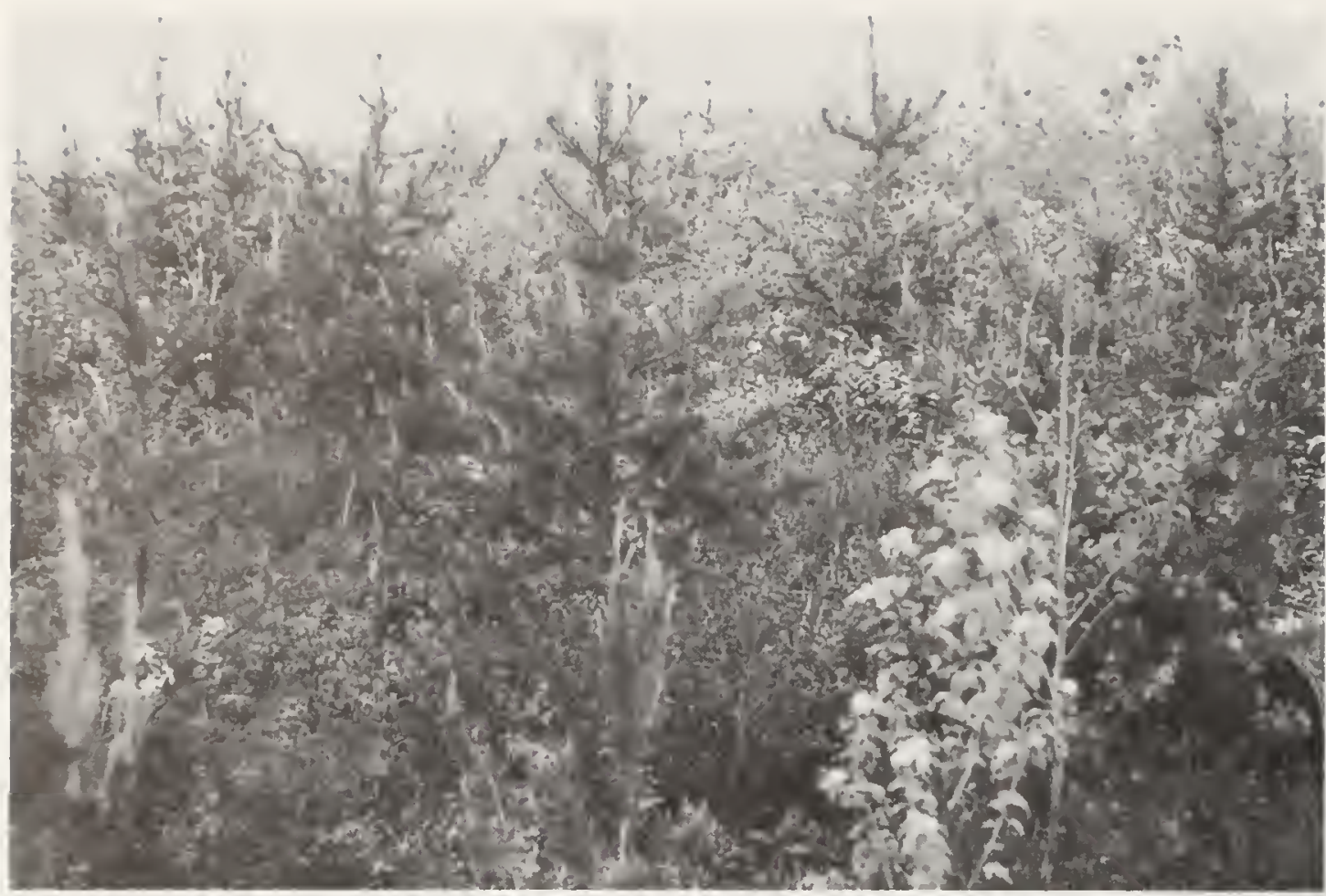

Fig. 6. New growth of mixed trees (M-1) and shrubs censused from 1987 to 1989 and in 1991 and 1992 when pines were six to 11 years old. Photographed in 1987.

birch snags remained on level ground in the census area, and numerous pine snags were left on steep hillsides outside the census area. Natural regeneration provided a dense growth of tall deciduous shrubs (mainly alder and pincherry) and young trees (primarily trembling aspen with fewer white birch). This growth was about $1.5 \mathrm{~m}$ high when censusing began in 1987, and exceeded $3 \mathrm{~m}$ in 1991. Blueberry, sheep laurel, honeysuckle, and sedges covered much of the ground. A variety of herbaceous plants, including bracken, filled in among the low shrubs as the season progressed. Topography was relatively level to gently rolling in the censused area, except for a deeper ravine edge at one end of the transect.

Herbicide was sprayed on the area in 1986 to control deciduous growth, but its effect was patchy and most shrubs that were sprayed soon resprouted. Censuses were conducted in 1987, 1988, 1989, 1991, and 1992, when pines were six to 11 years old.

\section{M-2. Young Mixed (Fig. 7)}

A young mixed stand with planted pines on the east side of Hwy 144, about $4 \mathrm{~km}$ north of Hwy 560 and 19 to 20 $\mathrm{km}$ southwest of Gogama (UTM squares 17MC3762 and 3763; map 41 P/12, Benneweis Twp.).

Jack pines were mixed with naturally occurring deciduous trees (white birch and trembling aspen) and these were immersed in a vigorous growth of numerous tall shrubs and tree saplings (alder, pincherry, willow, red maple, mountain ash, white birch, and trembling aspen), which were almost equal to the height of the pines in some places. Some tall white birches had been left standing and were scattered here and there, either still alive or providing tall snags. A few small black spruce and balsam fir were also scattered throughout. Blueberry, bracken, and honeysuckle were the common ground covers.

The terrain was gently rolling with a few wet depressions, and there were some swampy sections with tall spruce adjacent to the censused area. Censuses were carried out from 1985 to 1988 when trees were about 17 to 20 years of age.

\section{M-3. Medium-aged Mixed (Fig. 8)}

A medium-aged mixed forest immediately north of a narrow strip of planted pines on the north side of Hwy 560 , about $24 \mathrm{~km}$ east of Hwy 144 and 25 to $26 \mathrm{~km}$ southeast of Gogama (UTM squares 17MC5858, 5958, and 6058; map 41 P/5, Garvey Twp.).

Jack pines were mixed with about equal numbers of deciduous trees, predominantly trembling aspen with some white birch and white spruce. Pines and aspens tended to form single-species groves rather than being uniformly intermingled, indicating that planted pines had not survived well on some parts of this undulating ground with variable soil conditions. There were virtually no standing dead trees here. Although trees were the dominant taller vegetation, tall shrubs of pincherry and alder were found scattered thinly throughout with a few dense patches. The ground was densely covered with bracken in most places, with some honeysuckle and blueberry. As well, herbaccous plants were scattered throughout. 


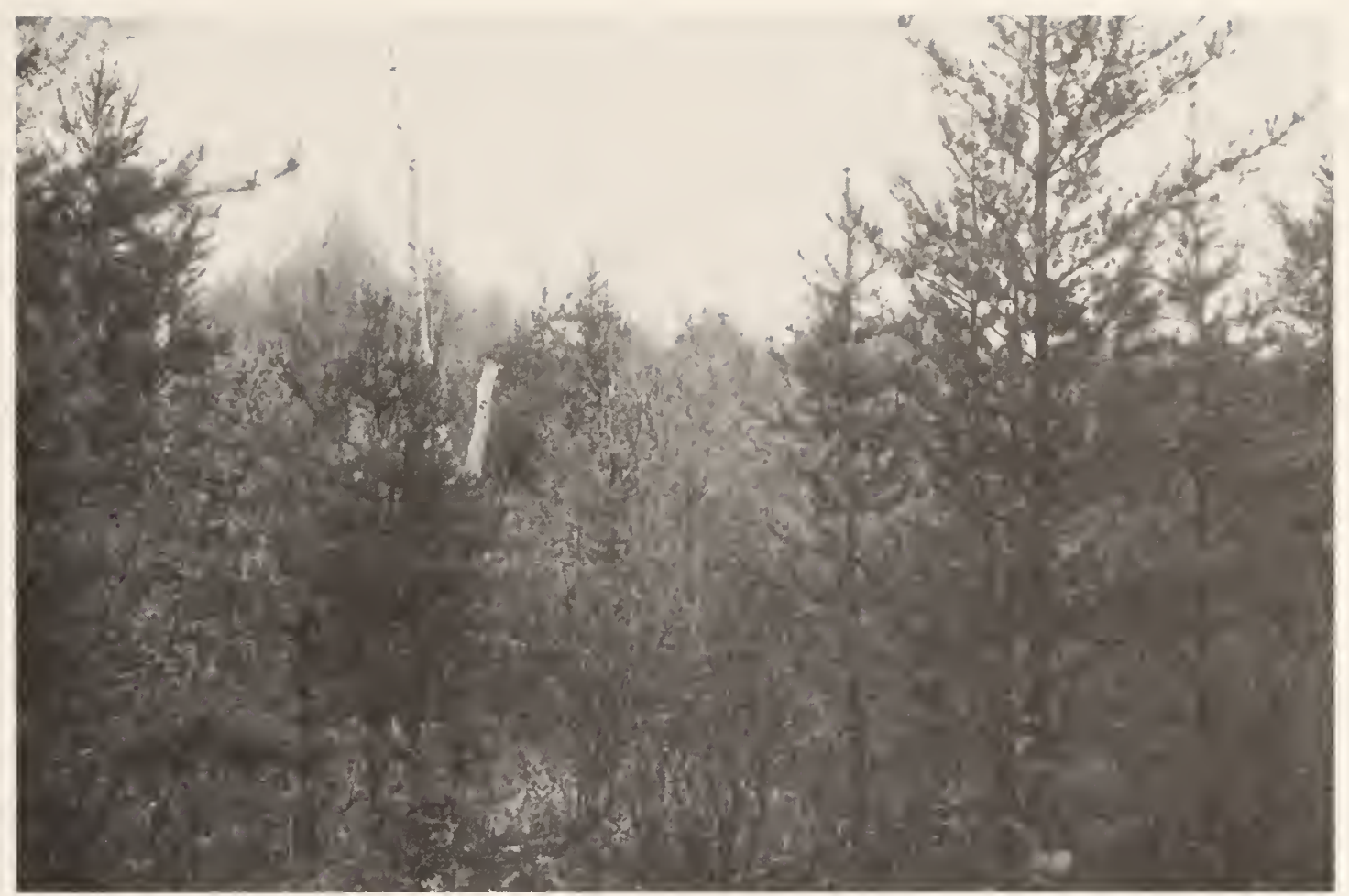

Fig. 7. Young mixed growth of pine, birch, and aspen (M-2) with numerous deciduous shrubs, censused from 1985 to 1988 when trees were 17 to 20 years old. Photographed in 1986.

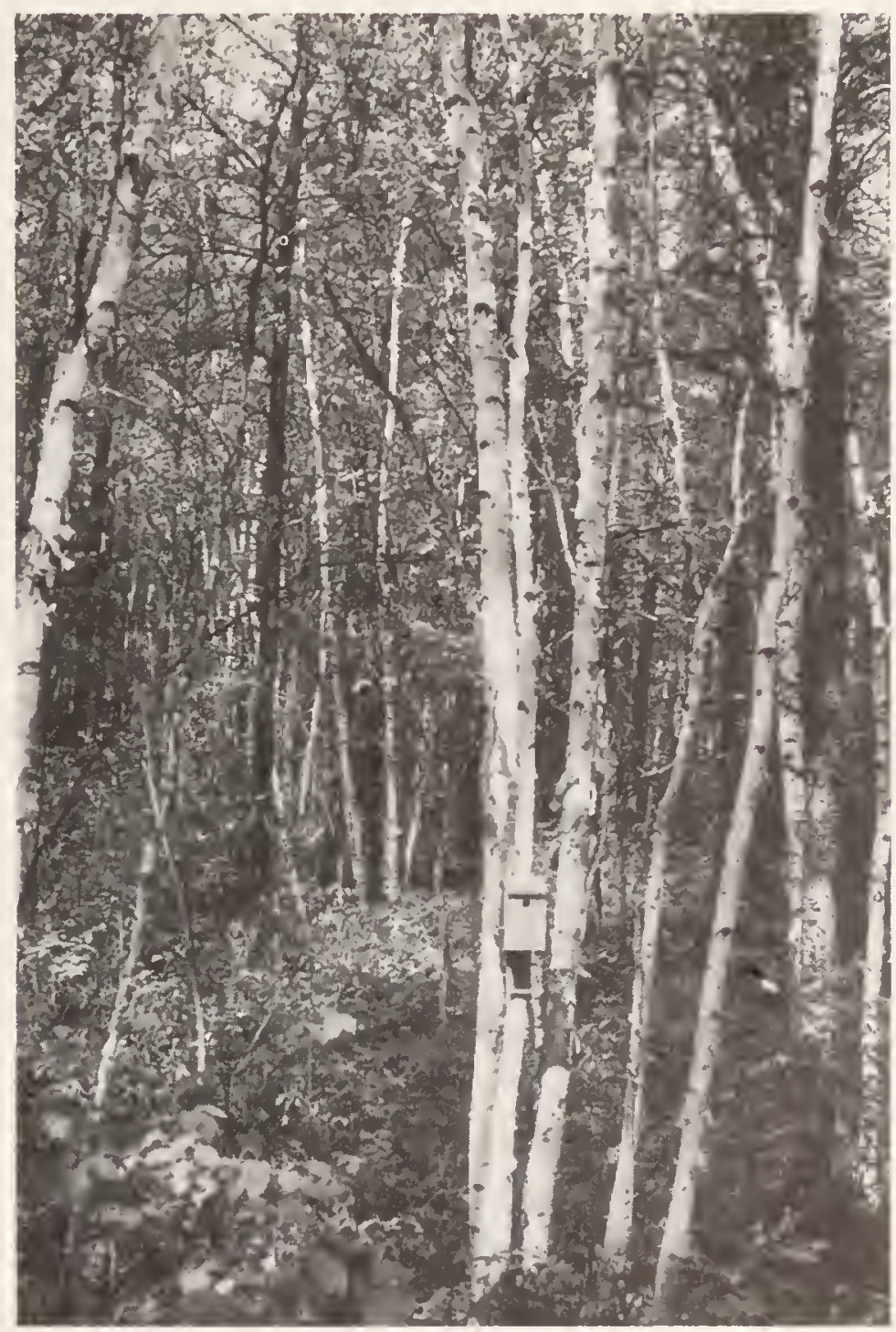

FIG. 8. Medium-aged mixed forest (M-3) censused from 1986 to 1988 when trees were about 40 to 42 years old. Photographed in 1986. 
This strip of mixed forest was bounded on the north by recently planted pines, heavily overgrown with deciduous shrubs and tree saplings, and on the south by pine forest of the same age. The topography was gently rolling. Censuses were conducted from 1986 to 1988 when trees were about 40 to 42 years old.

\section{HABITAT DATA}

Habitat data were gathered from 0.05 ha circles following the method of James and Shugart (1970). Centres of circles were located at marked intervals along transect lines, chosen by random number. Crown volume was estimated according to Balda (1969), choosing trees by the pointquarter method (Cottam and Curtis, 1956). Details of stand characteristics are provided in Table 1. Ages of trees were taken from Forest Resource Inventory maps.

In addition to birds recorded during censuses, at other times during the study we noted the presence of several additional species and supplemented our knowledge of all species. Casual observations were also reported by others working in this region. For 12 species that were characteristically present in pines (Yellow-bellied Flycatcher, Boreal Chickadee, Golden-crowned Kinglet, Hermit Thrush, Solitary Vireo, Nashville Warbler, Yellowrumped Warbler, Blackburnian Warbler, Ovenbird, Chipping Sparrow, White-throated Sparrow, and Darkeyed Junco) more specific habitat data were obtained in order to describe more precisely the preferences of each within the mosaic of available habitat. In general terms, we recorded information on trees, shrubs, and ground cover immediately surrounding male song perches, or, if known, nest sites. We also noted the plant species present, their proportions, heights, and spacing, and the extent of ground cover.

\section{CENSUSES}

All censuses were conducted in stands that had tree species of a similar age and covered an area of at least 40 ha. Bird populations were estimated with variable-strip transect counts using song cues only and adjusting numbers by coefficients of lateral detectability and cue-frequency production following methods outlined by Emlen (1971, 1977) and Christman (1984). This procedure is useful only for songbirds, although we made a note of other species seen, and counts for drumming grouse were likely as accurate as those for songbirds. Where sample sizes were very small, the maximum count rather than an average count was used, adjusting only by a lateral-detection factor as necessary.

Transects (one per habitat type) were measured with a stout cord and were marked every $50 \mathrm{~m}$ with surveyor's flagging tape. To minimize bias associated with small sample areas, transects were at least $1 \mathrm{~km}$ long if possible. By using transects that were at least $1 \mathrm{~km}$ long, we effectively sampled an area of at least 20 ha $(100 \mathrm{~m}$ on either side of the transect line) for most species. This exceeded the minimum area quoted by Erskine (1977) of 16 ha. And to minimize the bias associated with small plot sizes (Engstrom, 1981; Engel-Wilson et al., 1981), where possible we used a transect $2 \mathrm{~km}$ long, sampling an area of 40 ha. This ensured that even for species with rather quiet songs (Golden-crowned Kinglet and Boreal Chickadee) where we sampled only $30 \mathrm{~m}$ on either side of the transect, we still had an effective sampling area of 12 ha. For all other species the sampling area was 20 ha or more.

To minimize error associated with distance estimating, birds were not counted beyond $100 \mathrm{~m}$ from the transect line, although many could be heard much farther away. To facilitate comparisons among areas and with other workers, estimates for sample areas were adjusted to a standard value of the number of pairs of birds per square kilometre $\left(\mathrm{pr} / \mathrm{km}^{2}\right)$. Each transect was walked six times at a rate of $1 \mathrm{~km} / \mathrm{h}$, beginning between 0530 and $0630 \mathrm{~h}$ EDST. Half the counts were begun at one end of each transect, the other half at the other end. Whenever possible, in any one habitat simultaneous counts were made by two observers starting at opposite ends of the transect, and counting was done on successive days. Thus, weather permitting, all counts in any one habitat were made in a three-day period, to minimize changes associated with changing time of year. Counts were conducted between 26 May and 15 June and an effort was made to census the same stands on the same dates in subsequent years. Rainy or excessively windy days were avoided, calm, humid conditions being typical in this area at this time of year. Similarity coefficients between census areas were calculated following the methods of Gillespie and Kendeigh (1982).

Bird species names and sequence are those of the American Ornithologists' Union Check-list of North American Birds, 6th ed. (1983) and any subsequent supplements. Scientific names are found in the species accounts. 
TABLE 1. Habitat characteristics of seven censused stands (P-1 to P-4, M-1 to M-3) in the Gogama area, Sudbury District, Ontario.

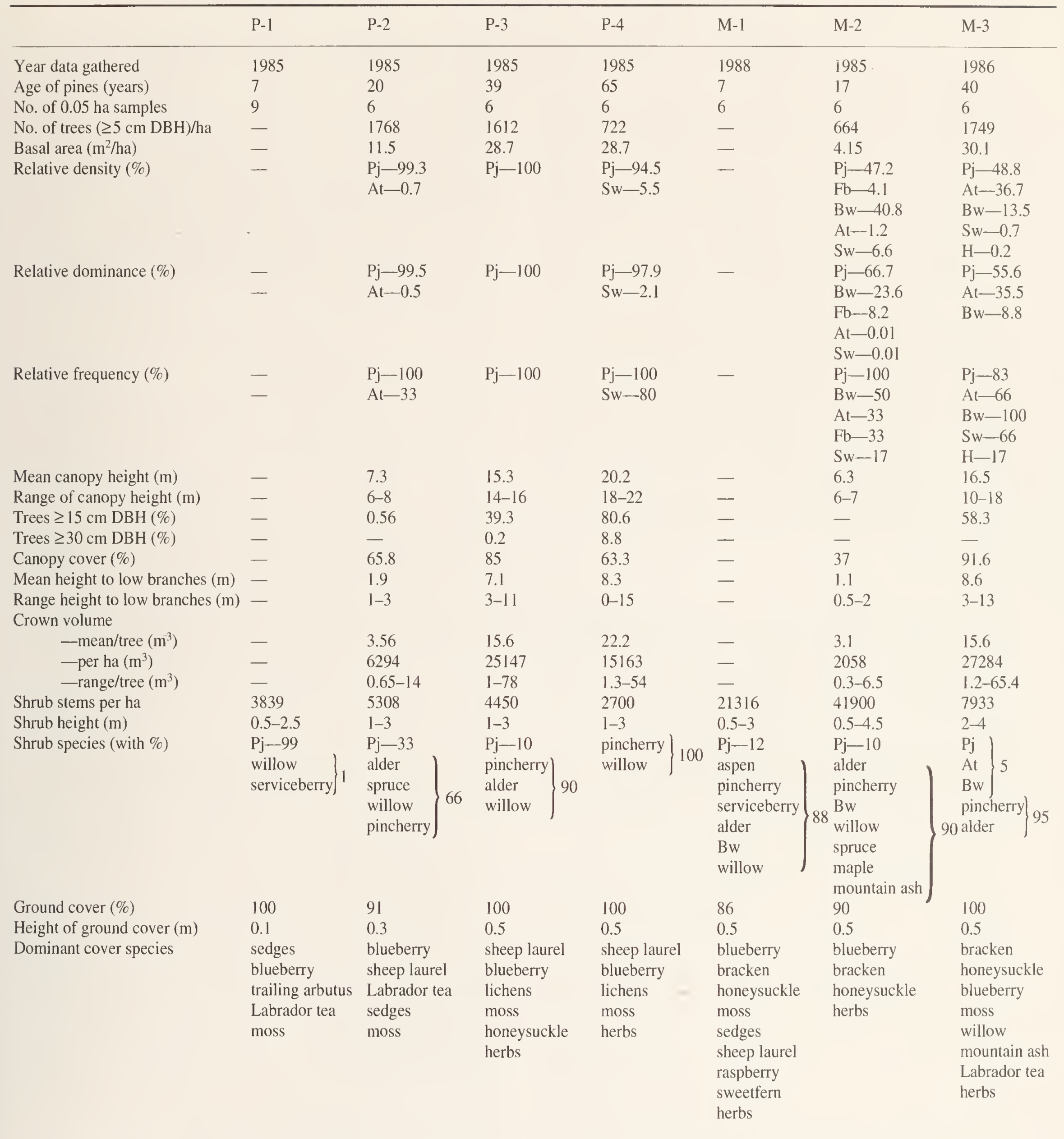

Specific nomenclature from Gleason and Cronquist (1963)
Pj-pine, jack-Pinus banksiana - pine, red-Pinus resinosa - pine, white-Pinus strobus At-aspen, trembling-Populus tremuloides
Bw-birch, white-Betula papyrifera -birch, yellow-Betula lutea
Sw-spruce, white-Picea glauca

Sb-spruce, black-Picea mariana
$\mathrm{Fb}$-fir, balsam-Abies balsamaea
$\mathrm{H}$-hemlock-Tsuga canadensis
maple-Acer sp.
maple, sugar-Acer saccharum
mountain ash-Sorbus sp.
Labrador tea-Ledum groenlandicum

blueberry-Vaccinium sp. sheep laurel-Kalmia angustifolia bracken-Pteridium aqualinum honeysuckle-Diervilla lonicera sedges-Cyperaceae mosses-Musci lichens-Thallophyta
raspberry-Rubus sp sweetfern-Myrica asplenifolia trailing arbutus-Epigaea repens willow-Salix sp.

pincherry-Prunus pensylvanica alder-Alnus sp.

serviceberry-Amelanchier sp. 


\section{Results}

\section{CENSUSES}

\section{P-1. New Growth of Pine (Fig. 2)}

A comparison of censused areas with respect to the birds found is presented in Table 2. In the new growth of pines the population of birds was the lowest of any of the censused areas (Table 3). Half the population was made up of a single species (White-throated Sparrow), a species that prefers edges and early-successional stages. The bird community was largely that of a field/shrub habitat rather than a wooded environment. Several species noted (Vesper Sparrow, Northern Harrier, American Kestrel, and Northern Flicker) require very open habitats with exposed ground while others (Brown Thrasher, Yellow Warbler, Chestnut-sided Warbler, and Song Sparrow) were attracted by patches of deciduous shrubby habitat. Species foraging predominantly in trees were scarcely seen and contributed nothing to the population size. There was a relatively low similarity to any other censused area (Table 2); the most similar was M-1, also an early-successional stage but with much more deciduous growth covering the ground.

\section{P-2. Young Pine (Fig. 3)}

In the young pine woods several species were remnants from the fauna of a younger, more open habitat (Northern Harrier, Northern Flicker, Common Yellowthroat, and Lincoln's Sparrow) or of more deciduous shrub growth (Alder Flycatcher and Chestnut-sided Warbler; Table 4). Species that were characteristically attracted to deciduous tree growth were either absent or present only in very small numbers (Table 2) where remnant patches of such vegetation were still present (Black-capped Chickadee, Veery, American Redstart, and Red-eyed Vireo).

The number of species inhabiting trees in P-2 was substantially greater than in P-1 (Table 2). Trees were still too small to be attractive to Solitary Vireo and Blackburnian Warbler, and Golden-crowned Kinglet was only beginning to appear. But six forest dwellers (Yellow-bellied Flycatcher, Boreal Chickadee, Hermit Thrush, Nashville Warbler, Yellow-rumped Warbler, and Ovenbird) were well established and could be as abundant here as in any other censused area (Table 4). Chipping Sparrow and White-throated Sparrow showed declines as the forest matured and closed in, whereas Dark-eyed Junco increased during the same time, but was also part of a core component of pine-dwelling species.

In young pines (P-2) the number of species was lower and population levels were only hall that found in similarly aged mixed pine/deciduous woods (M-2; Table 2). Species such as Red-eyed Vireo, Chestnut-sided Warbler, and American Redstart were much more numerous in mixed woods. Likewise, Rose-breasted Grosbeak, Canada Warbler, Mourning Warbler, and Black-and-white Warbler were present only in mixed woods. It is clear that a habitat component associated with deciduous growth was excluded in a growth of almost pure pines. The area of young pines, as might be expected, was most similar to the area of medium-aged pines (P-3; Table 2). However, there was also a fairly high similarity to similarly aged mixed woods (M-2), because many of the same species would be attracted to pines in both areas (compare Tables 4 and 8 ).

\section{P-3. Medium-aged Pine (Fig. 4)}

In pine forest of medium age a suite of 12 forest-inhabiting species formed the bulk of the population each year (Yellow-bellied Flycatcher, Boreal Chickadee, Goldencrowned Kinglet, Hermit Thrush, Solitary Vireo, Nashville Warbler, Yellow-rumped Warbler, Blackburnian Warbler, Ovenbird, Chipping Sparrow, White-throated Sparrow, and Dark-eyed Junco), whereas most other species occurred only sporadically or in small numbers (Table 5). In 1985 jack pine budworm in epidemic numbers contributed to very high numbers of Baybreasted Warbler in P-3 and P-4. Although some Tennessee Warbler, crossbills, and possibly other species may have been attracted in by budworm, Bay-breasted Warbler was the only species obviously contributing significantly to increased population levels. We have therefore excluded their numbers from the calculation of mean density (Table 2) so that the influence of this unusual situation is removed. Budworm numbers dropped much lower in 1986 and virtually disappeared in succeeding years (MacLeod, Jones, and Keizer, 1985, 1986; MacLeod, Jansons, and Keizer, 1987; MacLeod, Jansons, and Payne, 1988, 1989).

Although the area most similar to P-3 (medium-aged pine) was P-2 (young pine), the proportion of tree foragers had increased in P-3 to about two-thirds, compared to half in young pines. The similarity was almost as high with mature pines (P-4, Table 6) because tree foragers using pines accounted for most of the population in these three pine stands (Table 2). Adjacent mixed forest of the same age (M-3) had only a few more species and about the same population levels; however, the numbers of deciduous-foraging species accounted for about half the population total. The similarity coefficient is fairly high since many of the pine-dwelling species were the same in both areas (compare Tables 5 and 9). 
TABLE 2. Comparison of bird populations in the seven censused areas.

\begin{tabular}{|c|c|c|c|c|c|c|c|}
\hline & P-1 & P-2 & P-3 & P-4 & M-1 & M-2 & M-3 \\
\hline No. of years censused & 1 & 7 & 8 & 1 & 5 & 4 & 3 \\
\hline Age of pines (years) & 7 & $20-27$ & $39-47$ & 65 & $7-12$ & $17-20$ & $40-43$ \\
\hline Mean density of birds (pairs $/ \mathrm{km}^{2}$ ) & 141 & 334 & $350^{*}$ & $315^{*}$ & 361 & 791 & 380 \\
\hline No. of tree-foraging birds & 3 & 18 & 21 & 14 & 4 & 19 & 19 \\
\hline - percentage of mean density & + & 51 & 65 & 81 & 11 & 26 & 45 \\
\hline Tree foragers mainly using deciduous & 1 & 3 & 3 & 1 & 2 & 9 & 9 \\
\hline - percentage of mean density & + & 4 & 2 & + & 24 & 59 & 53 \\
\hline No. of ground- and shrub-foraging birds & 13 & 15 & 9 & 4 & 14 & 21 & 10 \\
\hline - percentage of mean density & 100 & 44 & 33 & 18 & 78 & 68 & 44 \\
\hline No. of aerial foragers & 4 & 5 & 3 & 2 & 7 & 7 & 3 \\
\hline P-4 & 24 & 66 & 72 & & & & \\
\hline M-1 & 54 & 44 & 38 & 22 & & & \\
\hline $\mathrm{M}-2$ & 36 & 66 & 54 & 42 & 50 & & \\
\hline M-3 & 22 & 62 & 64 & 54 & 34 & 58 & \\
\hline
\end{tabular}

TABLE 3. Census results (males or pairs $/ \mathrm{km}^{2}$ ) from a new growth of jack pines (P-1). A transect $1.9 \mathrm{~km}$ long was used in this open habitat where pines were about seven years old.

\begin{tabular}{ll}
\hline & 1985 \\
\hline Northern Harrier & + \\
American Kestrel & + \\
Ruby-throated Hummingbird & + \\
Northern Flicker & + \\
Tree Swallow & + \\
Blue Jay & + \\
Common Raven & + \\
Swainson's Thrush & 5.3 \\
Hermit Thrush & 7.9 \\
American Robin & 5.3 \\
Brown Thrasher & 7.9 \\
Yellow Warbler & + \\
Chestnut-sided Warbler & + \\
Chipping Sparrow & + \\
Clay-colored Sparrow & + \\
Vesper Sparrow & 18.4 \\
Song Sparrow & 15.8 \\
White-throated Sparrow & 69.8 \\
Dark-eyed Junco & 10.5 \\
Purple Finch & + \\
\hline TOTAL & 141 \\
\hline
\end{tabular}


TABLE 4. Census results (males or pairs $/ \mathrm{km}^{2}$ ) from a young pine woods (P-2). A transect $2 \mathrm{~km}$ long was used in all years. Trees were mainly 20 years old when censusing began, but a small section on the western end was 17 years old.

\begin{tabular}{|c|c|c|c|c|c|c|c|}
\hline & 1985 & 1986 & 1987 & 1988 & 1989 & 1990 & 1991 \\
\hline Northern Harrier & - & — & + & - & - & - & - \\
\hline Sharp-shinned Hawk & - & - & 一 & - & + & - & - \\
\hline Spruce Grouse & + & + & + & + & + & - & - \\
\hline Northern Flicker & - & + & + & - & - & - & - \\
\hline Yellow-bellied Flycatcher & 24.0 & 14.9 & 5.5 & 9.2 & 19.5 & 9.4 & 13.2 \\
\hline Alder Flycatcher & 5.0 & 2.5 & + & - & + & - & - \\
\hline Gray Jay & - & - & + & - & - & - & - \\
\hline Blue Jay & + & + & + & - & + & + & - \\
\hline American Crow & + & - & - & - & - & - & - \\
\hline Common Raven & + & - & - & - & + & + & - \\
\hline Black-capped Chickadee & + & - & - & + & - & + & + \\
\hline Boreal Chickadee & 15.0 & - & 16.5 & 28.5 & 33.0 & - & 8.3 \\
\hline Red-breasted Nuthatch & - & + & + & - & - & - & - \\
\hline Golden-crowned Kinglet & - & - & - & 5.0 & + & 10.0 & 15.0 \\
\hline Ruby-crowned Kinglet & + & - & - & - & 2.5 & - & - \\
\hline Veery & - & - & - & + & + & - & - \\
\hline Swainson's Thrush & 18.5 & 2.5 & 7.5 & + & - & - & 7.5 \\
\hline Hermit Thrush & 31.7 & 38.7 & 47.3 & 30.7 & 52.0 & 37.5 & 46.1 \\
\hline American Robin & 5.0 & 2.5 & 2.5 & - & - & - & - \\
\hline Cedar Waxwing & - & + & + & - & - & - & + \\
\hline Solitary Vireo & + & - & - & 2.5 & + & - & - \\
\hline Red-eyed Vireo & 10.0 & + & + & + & 5.0 & + & + \\
\hline Tennessee Warbler & - & 5.0 & 6.7 & - & - & - & - \\
\hline Nashville Warbler & 65.0 & 97.5 & 66.5 & 42.6 & 60.5 & 73.1 & 51.7 \\
\hline Chestnut-sided Warbler & 10.0 & + & - & - & - & - & + \\
\hline Magnolia Warbler & 13.3 & + & + & 6.5 & + & + & + \\
\hline Yellow-rumped Warbler & 41.1 & 52.0 & 74.9 & 53.0 & 65.0 & 63.4 & 73.0 \\
\hline Blackburnian Warbler & - & - & - & - & - & + & - \\
\hline American Redstart & + & - & - & - & - & - & - \\
\hline Ovenbird & 16.0 & 26.0 & 31.6 & 29.4 & 36.5 & 43.9 & 46.3 \\
\hline Common Yellowthroat & + & + & - & - & - & - & - \\
\hline Chipping Sparrow & 20.0 & 15.0 & 50.0 & 30.0 & 15.0 & 10.0 & 17.7 \\
\hline Lincoln's Sparrow & + & - & - & - & - & - & - \\
\hline White-throated Sparrow & 50.0 & 53.5 & 53.1 & 27.5 & 25.3 & 7.5 & 9.8 \\
\hline Dark-eyed Junco & 20.0 & 18.9 & 32.9 & 31.1 & 20.3 & 35.0 & 62.5 \\
\hline Purple Finch & + & + & + & + & - & - & - \\
\hline Crossbill sp. & + & + & - & - & - & - & - \\
\hline Evening Grosbeak & + & + & + & - & + & + & + \\
\hline TOTAL & 345 & 329 & 395 & 296 & 335 & 290 & 354 \\
\hline
\end{tabular}


TABLE 5. Census results (males or pairs $/ \mathrm{km}^{2}$ ) from a forest of jack pine trees of about 39 years of age when censusing began (P-3). Results were from a transect $2 \mathrm{~km}$ long.

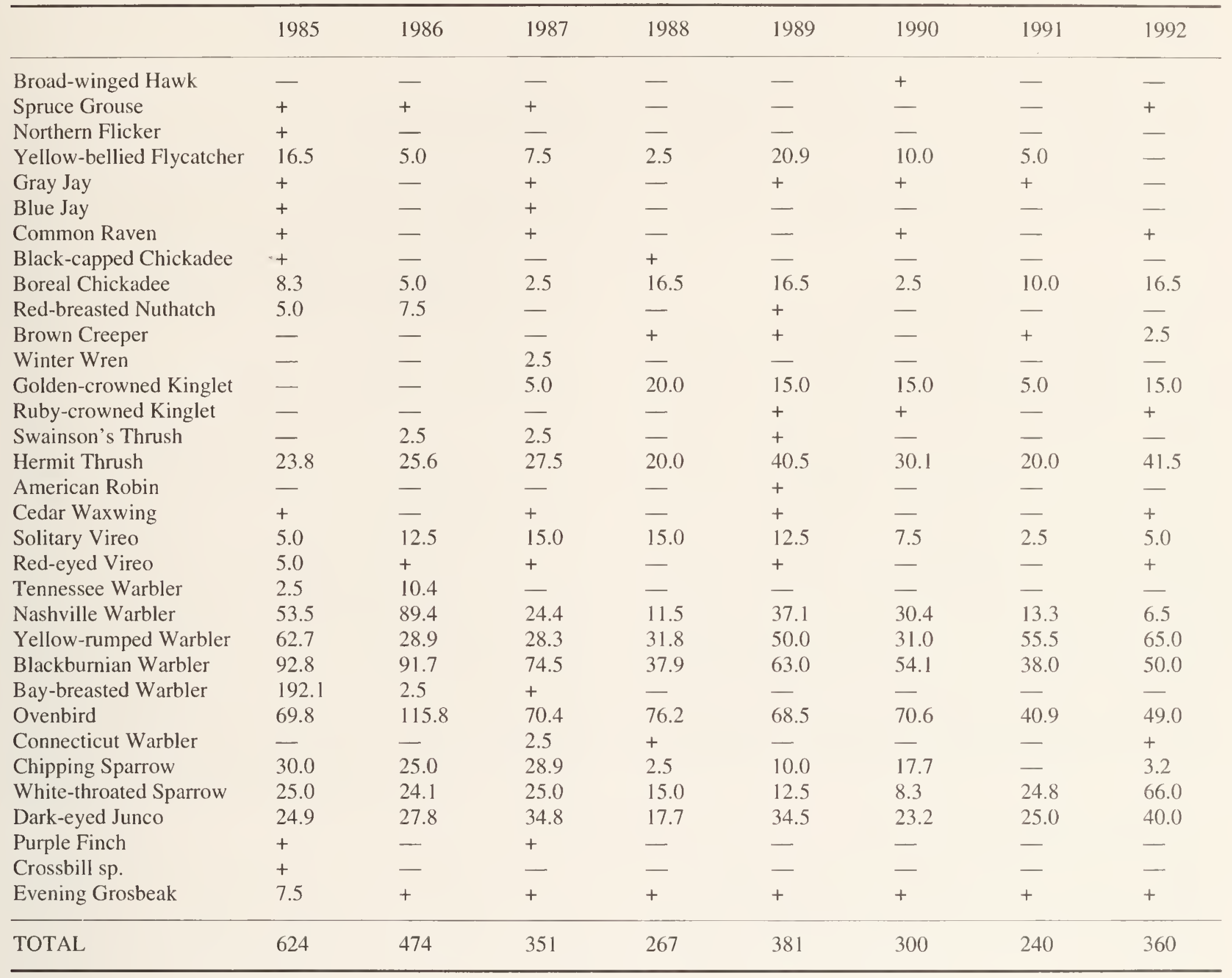

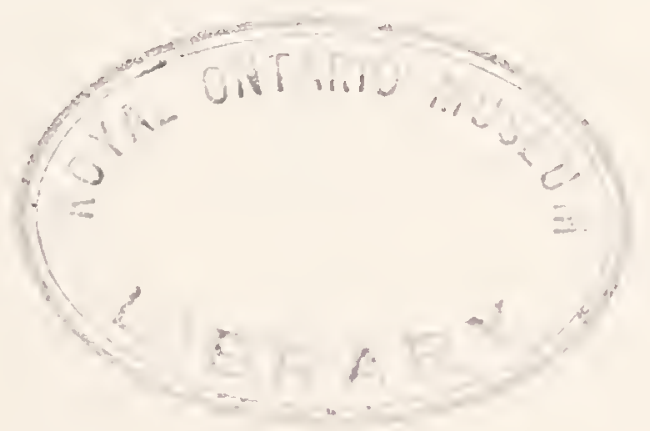




\section{P-4. Mature Pine (Fig. 5)}

The somewhat more open nature of the mature pine forest may account for the high numbers of Chipping Sparrow. Noticeably scarce to absent in the young to mature pine forest were cavity nesters, particularly woodpeckers. The most numerous was the Boreal Chickadee, which needs only very small cavities. Even at that, we located only one natural nest in the centre of an old stump. The nest itself was actually below ground level. Suitable snags or dead trees for any of the cavity nesters were virtually absent in this type of managed forest.

\section{M-1. New Growth of Mixed (Fig. 6)}

Mixed growth at a young early-successional stage was dominated by two species that appear as soon as a substantial cover of vegetation develops (White-throated Sparrow and Common Yellowthroat; Table 7). As shrub growth increased in height, Alder Flycatcher and Chestnut-sided Warbler soon became as common. Lincoln's Sparrow and Mourning Warbler also found some suitable habitat. As vegetation reached about $3 \mathrm{~m}$ in height. species more typical of older woodlands-Ruffed Grouse, Veery, Hermit Thrush. Red-eyed Vireo, and Nashville Warbler-began to appear (compare Tables 7 and 8 ). The population was still heavily dominated by ground and shrub foragers. Early-successional species could be very common (100 to $200 \mathrm{pr} / \mathrm{km}^{2}$ ) and population levels were substantial at this stage, even though only a few species contributed to the bulk of the numbers.

\section{M-2. Young Mixed (Fig. 7)}

In the mixed growth of young pines and deciduous trees with numerous shrubs, many more bird species found suitable habitat (Table 8), and some additional species wandered into the area from adjacent habitat. Early-successional species, such as Alder Flycatcher, Chestnutsided Warbler, and White-throated Sparrow, were still common to abundant, but declined as the trees matured, while Common Yellowthroat, Mourning Warbler, and Lincoln's Sparrow were gone or nearly gone.

Several new mid-successional species, such as Blue Jay, Magnolia Warbler, Black-and-white Warbler, and American Redstart, had become common. The number of species that would persist as the forest matured, including Ruffed Grouse, Yellow-bellied Flycatcher, Blue Jay, Black-capped Chickadee, Red-breasted Nuthatch, Winter Wren, Veery, Swainson's Thrush, Hermit Thrush, Redeyed Vireo, Nashville Warbler, Yellow-rumped Warbler,
Rose-breasted Grosbeak, and Evening Grosbeak, had increased substantially. The woods were still dominated by ground- and shrub-foraging species; of species attracted by tree growth, nearly 60 per cent were those favouring deciduous components (Table 2).

In M-2 several cavity nesters (Downy Woodpecker, Hairy Woodpecker, Northern Flicker, Tree Swallow, Black-capped Chickadee, and Red-breasted Nuthatch) were undoubtedly attracted by the standing dead trees. The increasing populations of forest dwellers, with the still substantial population of early-successional species, plus the combination of coniferous and deciduous trees, contributed to the highest densities and the greatest number of species recorded among any of the areas censused.

\section{M-3. Medium-aged Mixed (Fig. 8)}

In the medium-aged mixed forest of jack pines with trembling aspens and white birches where trees were in excess of $10 \mathrm{~m}$ in height, some of the diversity of a younger mixed wood had gone (Table 9). The number of earlysuccessional species that had left was greater than the number of late-successional species that had arrived. Least Flycatcher, Philadelphia Vireo, Black-throated Blue Warbler, Blackburnian Warbler, and Ovenbird were the main additions. A very few Golden-crowned Kinglet, Solitary Vireo, Tennessee Warbler, Scarlet Tanager, and Dark-eyed Junco occurred where pockets of forest were suitable for at least occasional use. In this forest there were now more tree than ground and shrub foragers, but they made up about equal proportions of the population (Table 2).

In the pine forests ( 20 or more years old), we recorded about 20 species a year regardless of age, usually the same species. An additional 18 species were recorded over a number of years, but in general they contributed little to the overall population. There was considerable difference, however, in both species numbers and population sizes recorded between the 20-year-old and the 40year-old mixed forests, with the more gradual disappearance of early-successional species and a concomitant appearance of other species. The bird community also seemed more dynamic in mixed forests; while more species were likely to be recorded in any one year (as many as 30 in any given year and nearly 50 over several years), the numbers of any one species present seemed to fluctuate considerably. Even for the half-dozen species likely to be recorded every year, numbers were not always substantial. 
TABLE 6. Census results (males or pairs $/ \mathrm{km}^{2}$ ) in a mature pine forest of about 65 years of age (P-4). A transect $1.5 \mathrm{~km}$ long was used.

\begin{tabular}{ll}
\hline & 1985 \\
\hline Sharp-shinned Hawk & + \\
Yellow-bellied Flycatcher & 3.3 \\
Gray Jay & + \\
Black-capped Chickadee & + \\
Boreal Chickadee & 3.3 \\
Red-breasted Nuthatch & 6.7 \\
Hermit Thrush & 18.7 \\
Solitary Vireo & + \\
Tennessee Warbler & 6.7 \\
Nashville Warbler & 22.1 \\
Yellow-rumped Warbler & 61.2 \\
Blackburnian Warbler & 63.4 \\
Bay-breasted Warbler & 77.7 \\
Ovenbird & 23.4 \\
Chipping Sparrow & 73.3 \\
White-throated Sparrow & 20.5 \\
Dark-eyed Junco & 10.0 \\
Purple Finch & 3.3 \\
Crossbill sp. & + \\
Evening Grosbeak & + \\
\hline TOTAL & 393 \\
\hline
\end{tabular}

TABLE 7. Census results (males or pairs $/ \mathrm{km}^{2}$ ) for a new growth of jack pines mixed with deciduous regeneration (M-1). Trees were six years old when censusing began. A transect $1 \mathrm{~km}$ long was used in this early-successional stage.

\begin{tabular}{|c|c|c|c|c|c|}
\hline & 1987 & 1988 & 1989 & 1991 & 1992 \\
\hline Mallard & + & - & - & - & - \\
\hline Red-tailed Hawk & + & - & - & - & - \\
\hline American Kestrel & + & - & + & - & + \\
\hline Ruffed Grouse & - & 5.0 & - & - & - \\
\hline Ruby-throated Hummingbird & - & + & + & - & - \\
\hline Northern Flicker & + & + & + & + & + \\
\hline Alder Flycatcher & - & - & 33.3 & 112.0 & 5.0 \\
\hline Eastern Kingbird & - & - & + & - & - \\
\hline Tree Swallow & + & - & - & - & - \\
\hline Blue Jay & + & - & - & + & - \\
\hline Common Raven & + & - & - & - & - \\
\hline Veery & - & - & 10.0 & 15.0 & - \\
\hline Hermit Thrush & - & - & 10.0 & 5.0 & - \\
\hline American Robin & - & - & - & 10.0 & - \\
\hline Brown Thrasher & - & - & 5.0 & - & 5.0 \\
\hline Cedar Waxwing & 一 & - & + & - & - \\
\hline Red-eyed Vireo & + & - & - & 20.0 & 5.0 \\
\hline Nashville Warbler & - & - & 5.0 & 13.0 & 39.0 \\
\hline Chestnut-sided Warbler & - & 5.0 & 15.0 & 70.0 & 30.0 \\
\hline Yellow-rumped Warbler & - & - & - & - & 20.0 \\
\hline Mourning Warbler & 30.2 & 5.0 & 15.0 & + & 30.0 \\
\hline Common Yellowthroat & 105.4 & 100.9 & 66.7 & 91.8 & 37.5 \\
\hline Lincoln's Sparrow & 10.0 & 10.0 & 20.0 & 5.0 & 10.0 \\
\hline White-throated Sparrow & 200.0 & 125.0 & 50.0 & 196.2 & 247.0 \\
\hline Dark-eyed Junco & - & $\ldots$ & - & - & 10.0 \\
\hline TOTAL & 346 & 251 & 230 & 538 & 439 \\
\hline
\end{tabular}


TABLE 8. Census results (males or pairs $/ \mathrm{km}^{2}$ ) from a young mixed jack pine/deciduous woods (M-2). Trees were 17 years old when censusing began. A transect $1.5 \mathrm{~km}$ long was used.

\begin{tabular}{|c|c|c|c|c|}
\hline & 1985 & 1986 & 1987 & 1988 \\
\hline American Kestrel & - & - & + & - \\
\hline Ruffed Grouse & 5.0 & 6.6 & 22.0 & 19.8 \\
\hline Common Snipe & - & + & - & + \\
\hline Yellow-bellied Sapsucker & - & - & + & - \\
\hline Downy Woodpecker & - & + & + & + \\
\hline Hairy Woodpecker & + & + & - & 3.3 \\
\hline Northern Flicker & + & + & 15.4 & - \\
\hline Olive-sided Flycatcher & - & + & - & - \\
\hline Yellow-bellied Flycatcher & 5.0 & 3.3 & 6.6 & - \\
\hline Alder Flycatcher & 73.5 & 34.3 & 19.8 & 13.2 \\
\hline Least Flycatcher & 15.0 & 3.3 & - & - \\
\hline Tree Swallow & + & - & + & - \\
\hline Gray Jay & + & + & + & - \\
\hline Blue Jay & 5.0 & 6.6 & 3.3 & 3.3 \\
\hline American Crow & - & - & + & - \\
\hline Black-capped Chickadee & - & 6.6 & 6.6 & 19.8 \\
\hline Red-breasted Nuthatch & + & - & - & 6.6 \\
\hline Winter Wren & - & - & 6.6 & 3.3 \\
\hline Ruby-crowned Kinglet & + & - & - & + \\
\hline Eastern Bluebird & - & + & - & - \\
\hline Veery & 28.5 & 26.5 & 13.2 & 20.0 \\
\hline Swainson's Thrush & - & 31.5 & 48.0 & 19.9 \\
\hline Hermit Thrush & 36.0 & 24.6 & 20.5 & 26.3 \\
\hline American Robin & 25.0 & 11.7 & 19.9 & 10.0 \\
\hline Cedar Waxwing & + & - & + & + \\
\hline Solitary Vireo & - & - & - & + \\
\hline Red-eyed Vireo & 67.2 & 66.6 & 60.5 & 56.0 \\
\hline Nashville Warbler & 53.2 & 50.4 & 42.9 & 40.6 \\
\hline Chestnut-sided Warbler & 460.3 & 109.6 & 134.4 & 110.0 \\
\hline Magnolia Warbler & 46.7 & 89.5 & 83.7 & 90.2 \\
\hline Yellow-rumped Warbler & 20.0 & 44.2 & 26.1 & 21.5 \\
\hline Black-throated Green Warbler & + & - & - & - \\
\hline Black-and-white Warbler & 45.4 & 25.4 & 39.1 & 19.8 \\
\hline American Redstart & 85.3 & 46.0 & 91.7 & 66.0 \\
\hline Mourning Warbler & 15.0 & 9.9 & - & - \\
\hline Common Yellowthroat & 5.0 & + & 6.6 & - \\
\hline Canada Warbler & 10.0 & 13.2 & - & - \\
\hline Rose-breasted Grosbeak & 25.0 & 3.3 & + & 10.0 \\
\hline Chipping Sparrow & 5.0 & - & - & - \\
\hline White-throated Sparrow & 109.1 & 69.3 & 61.9 & 37.9 \\
\hline Dark-eyed Junco & - & - & 3.3 & 13.2 \\
\hline Rusty Blackbird & - & + & - & - \\
\hline Common Grackle & - & - & + & + \\
\hline Purple Finch & + & + & + & - \\
\hline Crossbill sp. & + & + & - & - \\
\hline American Goldfinch & - & + & - & - \\
\hline Evening Grosbeak & + & + & + & - \\
\hline TOTAL & 1140 & 682 & 732 & 611 \\
\hline
\end{tabular}


TABLE 9. Census results (males or pairs $/ \mathrm{km}^{2}$ ) from a mixed jack pine/deciduous forest that was about 40 years old when censusing began (M-3). A transect $2 \mathrm{~km}$ long traversed this stand.

\begin{tabular}{|c|c|c|c|}
\hline & 1986 & 1987 & 1988 \\
\hline Ruffed Grouse & 7.5 & 10.0 & 10.0 \\
\hline Yellow-bellied Sapsucker & + & + & - \\
\hline Pileated Woodpecker & - & + & - \\
\hline Yellow-bellied Flycatcher & - & + & 10.0 \\
\hline Least Flycatcher & 42.5 & 38.3 & 32.3 \\
\hline Blue Jay & - & - & 5.0 \\
\hline Black-capped Chickadee & 20.0 & 7.5 & 10.0 \\
\hline Red-breasted Nuthatch & 5.0 & - & 2.5 \\
\hline Winter Wren & 5.0 & 2.5 & 2.5 \\
\hline Golden-crowned Kinglet & - & - & 2.5 \\
\hline Ruby-crowned Kinglet & - & + & - \\
\hline Veery & - & 19.0 & 10.0 \\
\hline Swainson's Thrush & 7.5 & 10.0 & 10.0 \\
\hline Hermit Thrush & 37.5 & + & 5.0 \\
\hline Cedar Waxwing & + & - & + \\
\hline Solitary Vireo & - & - & 2.5 \\
\hline Philadelphia Vireo & 10.0 & 23.0 & 21.3 \\
\hline Red-eyed Vireo & 69.7 & 47.2 & 25.0 \\
\hline Tennessee Warbler & 2.5 & - & - \\
\hline Nashville Warbler & 36.3 & 19.6 & 2.5 \\
\hline Magnolia Warbler & + & 5.0 & 2.5 \\
\hline Black-throated Blue Warbler & 20.5 & 21.5 & 15.0 \\
\hline Yellow-rumped Warbler & 19.9 & 5.0 & 5.0 \\
\hline Blackburnian Warbler & 61.8 & 59.6 & 23.3 \\
\hline Black-and-white Warbler & 10.0 & - & 2.5 \\
\hline Ovenbird & 136.5 & 99.5 & 65.1 \\
\hline Scarlet Tanager & 5.0 & 2.5 & 6.7 \\
\hline Rose-breasted Grosbeak & 5.0 & - & - \\
\hline White-throated Sparrow & 12.5 & - & - \\
\hline Dark-eyed Junco & 2.5 & - & - \\
\hline Purple Finch & - & + & - \\
\hline Evening Grosbeak & + & + & - \\
\hline TOTAL & 497 & 371 & 271 \\
\hline
\end{tabular}




\section{SPECIES ACCOUNTS}

We noted 80 different bird species while working in various ages of pine or mixed pine/deciduous forests during the breeding season, and an additional three species were reported to us. About half of these 83 species made specific use of pines to some extent. Of those using pines, only 20 species made extensive use of pine forest, although two of these were present only when budworm levels were high. Others, while largely associated with openings in the canopy or with deciduous growth, did make some use of pines. especially areas regrowing with pines.

\section{American Black Duck, Anas rubripes}

Rare in wooded areas; found nesting once in an area with young pines some distance from water.

\section{Mallard, Anas platyrhynchos}

Rare in wooded areas; apparently looked for nesting cover in young open pine regeneration near lakes, where the species has been known to nest (Peck and James, 1983).

\section{Northern Harrier, Circus cyaneus}

Rare, found nesting adjacent to, and frequently seen hunting in, young regeneration, where there was still open space between trees.

\section{Sharp-shinned Hawk, Accipiter striatus}

Rare, but seen more frequently than Northern Harrier; seen in pines of any height above $6 \mathrm{~m}$. Several unoccupied nests seen in pines 40 to 50 years old may have been constructed by this species.

\section{Northern Goshawk, Accipiter gentilis}

Rare, but known to hunt in any pine forest once trees reached about $6 \mathrm{~m}$ in height. One nest site reported in a patch of mature to overmature jack pines.

\section{Broad-winged Hawk, Buteo platypterus}

Seen rarely; found nesting in a mature jack pine in a mixed forest. Typically hunts in deciduous components of a forest, but not exclusively so.

\section{Red-tailed Hawk, Buteo jamaicensis}

Relatively rare; seen hunting over very young regeneration and found nesting in a thin strip of mature jack pine trees beside a bog.

\section{American Kestrel, Falco sparverius}

Rare, but easily seen; nested in old woodpecker cavities in large snags left standing in cutovers or burns. Hunted near their nests in open areas, and could be expected in any such area of 50 or more ha.
Merlin, Falco columbarius

Very rare; found nesting in a jack pine grove with trees about $15 \mathrm{~m}$ high, near openings, where they prefer to hunt.

\section{Spruce Grouse, Dendragapus canadensis}

A characteristic bird of jack pine forests. Began to appear in pines by the time trees reached $2 \mathrm{~m}$ in height and was at maximum abundance in young pines (P-2). Trees of 11 to 21 years old in the Gogama area had the highest densities of Spruce Grouse recorded anywhere in North America (Szuba and Bendell, 1983). Populations decline as the forests mature.

\section{Ruffed Grouse, Bonasa umbellus}

A relatively common species, preferring the deciduous components of mixed pine/deciduous forests. Began to occur when deciduous growth exceeded $2 \mathrm{~m}$ in height; appeared to reach maximum densities in younger forests of about 20 years old.

\section{Solitary Sandpiper, Tringa solitaria}

Rare; seen several times in summer in a beaver-flooded area surrounded by young pine woods, where it could have nested.

\section{Common Snipe, Gallinago gallinago}

Rare; attracted only by wet depressions with standing water among trees.

\section{Great Gray Owl, Strix nebulosa}

Young of the year reported in a 40-year-old pine forest. This rare species could have nested, and certainly could hunt, in this forest. Also observed in winter in adjacent mixed pine/deciduous forest.

\section{Short-eared Owl, Asio flammeus}

Rare; may have been only a migrant, but was reported from a newly planted area with grasses and sedges, where the open nature of the habitat afforded the species favourable conditions.

\section{Common Nighthawk, Chordeiles minor}

Uncommon; usually seen foraging in the air over pines, especially recently planted areas, and younger woods. Could have nested in such areas where trees were not yet contiguous.

\section{Ruby-throated Hummingbird, Archilochus colubris} Uncommon but regular in very young regrowth where flowers were available. Probably required mixed forests in adjacent areas where sapsucker feeding holes were available in birches and aspens. 
Yellow-bellied Sapsucker, Sphyrapicus varius

Encountered rarely, usually in mixed pine/deciduous forest, but made at least occasional use of pine forest. Drilled sap holes, usually in birch or aspen, but occasionally also in young pines.

\section{Downy Woodpecker, Picoides pubescens}

Seen rarely, and then only in the younger mixed woods, where some larger birch snags were available for nesting.

\section{Hairy Woodpecker, Picoides villosus}

Seen rarely and only in the younger mixed woods, where large deciduous snags were available for nesting.

\section{Black-backed Woodpecker, Picoides arcticus}

One bird was seen foraging on several occasions in pine forest of about 45 years of age. The absence of trees large enough for nesting probably limited the species in most managed forests.

\section{Northern Flicker, Colaptes auratus}

Relatively common; usually seen only in very young regeneration (pines or mixed) where openings to the ground were numerous. The presence of large snags is essential to nesting.

\section{Pileated Woodpecker, Dryocopus pileatus}

Seldom ever seen passing through older forests (pine or deciduous). There were no snags large enough for nesting and there were few dead trees or logs and few, if any, trees with heart rot to attract this species.

\section{Olive-sided Flycatcher, Contopus borealis}

Rare; preferred very open swampy woods, but regularly foraged from and nested in jack pines adjacent to riparian areas dry enough for scattered pines.

\section{Yellow-bellied Flycatcher, Empidonax flaviventris}

A characteristic species of the pine forest, rare to absent when deciduous trees exceeded about 10 per cent of the cover. Pines needed to be only 6 to $8 \mathrm{~m}$ high, but canopy cover was always in excess of 75 per cent and trees could be very dense. Birds were never very abundant (despite a plethora of flies) and seemed to reach maximum density in younger forests where branches were near the ground. Medium to tall shrubs were almost absent in younger pine woods occupied by this species; however, where trees were taller and the canopy higher, shrub cover was present and may have covered as much as 50 per cent of the ground. Low shrubs (sheep laurel and blueberry) typically covered almost all the ground in these pine forests, including where this ground-nesting species took up residence.

\section{Alder Flycatcher, Einpidonax alnorum}

Commonly found only in young stands where numerous tall deciduous shrubs afforded suitable habitat. Appeared about six or seven years after cutting or burning and was gone by 20 to 25 years as trees matured and shaded the ground.

\section{Least Flycatcher, Empidonax minimus}

Locally common only when trees exceeded $10 \mathrm{~m}$ in height, and invariably associated with trembling aspen and/or white birch. A few pines may have been interspersed with the deciduous trees, but the species was rarely known to nest in pines. Usually there had to be sufficient deciduous tree cover for a small group of territories; a pair seldom ever occurred in isolation.

\section{Eastern Kingbird, Tyrannus tyrannus}

Rare; found where a few scattered large trees bordered very young regeneration with open areas over which it could forage.

\section{Tree Swallow, Tachycineta bicolor}

Foraged over any forest, but was never common because of a scarcity of nest sites, i.e., old woodpecker cavities in snags.

\section{Gray Jay, Perisoreus canadensis}

Seen only sporadically in pine forests and probably did not nest there; occasionally foraged through from adjacent spruce swamps.

\section{Blue Jay, Cyanocitta cristata}

Uncommon; seen only in predominantly deciduous portions of mixed forests, but occasionally foraged through pines. Could have nested in any mixed forest 15 to 20 years old or older.

\section{American Crow, Corvus brachyrhynchos}

Only a few birds seen, usually near roads, railroads, or buildings where open places afforded foraging sites. Taller pines adjacent to openings served as nest sites for this species.

\section{Common Raven, Corvus corax}

Commonly seen and heard near and over pine or mixed forests; several nests found in groves of mature pines. In forested areas, it would forage in recently cut, planted, or burned sections and road edges.

\section{Black-capped Chickadee, Parus atricapillus}

Common in predominantly deciduous portions of mixed forest, where it nested. Foraged in pines to some extent, especially during the winter. 


\section{Boreal Chickadee, Parus hudsonicus}

Regularly found only where jack pine was the tree cover. Pines needed to be only 4 to $6 \mathrm{~m}$ high. Densities were highest where trees were near $10 \mathrm{~m}$ high, and declined somewhat as forests matured. Nest boxes were placed in both 20- and 40-year-old stands, but only in the younger stands were they used regularly. In each survey year only one occupied box was ever close enough to a transect line that census results might have been influenced by it. Overmature forest would provide more potential nest sites and therefore would probably have had higher densities of this cavity nester. The species was not common, but populations were undoubtedly somewhat higher than censuses indicated as the birds became very quiet once nesting was under way. Birds readily accepted nest boxes, but squirrels interfered with most nests. In nesting areas canopy cover was usually above 75 per cent (and often close to 100 per cent), but well-spaced trees with closure only somewhat above 50 per cent were occasionally chosen. Tall shrubs were typically few to absent and seemed unnecessary because birds foraged only in the pines.

\section{Red-breasted Nuthatch, Sitta canadensis}

Rare; a typically coniferous-forest inhabitant, which, like woodpeckers, had few opportunities to nest in these managed pine forests. Found as frequently in mixed forests, probably because deciduous snags provided better nesting opportunities for this cavity nester. Occurred once trees reached about $6 \mathrm{~m}$ in height.

\section{Brown Creeper, Certhia americana}

Found with young in a nearby unmanaged patch of pines more than 100 years old. Although it might therefore have been expected in pine forests, none of the managed areas censused provided nesting opportunities for this species. Managed jack pine forests would not likely begin to provide nesting opportunities for this species until they were 70 to 80 years of age or older, when some larger dead or dying trees might be expected.

\section{Winter Wren, Troglodytes troglodytes}

Rare; associated with moist depressions. Where it did occur, the type of forest was not as important as the local conditions. The sandy soils underlying the censused forests generally seemed to result in conditions that were too dry for this species.

\section{Golden-crowned Kinglet, Regulus satrapa}

Foraging readily in pine trees, but occurred only where a small component of the forest was white spruce, which afforded nesting sites. Deciduous trees were found in some territories, but were unnecessary. The species appeared when trees reached about 20 years of age, but was never numerous at any age of forest, perhaps because spruce was never abundant.

\section{Ruby-crowned Kinglet, Regulus calendula}

Generally not a bird of pine forest, usually just wandering in briefly to forage from adjacent spruce swamps. On rare occasions a male or a pair remained for some time in pine forest and some spruce trees and conceivably could have nested, although we never had an indication that they did so. The species seems to be dependent upon spruce for nesting (Peck and James, 1987), and there were few spruces to attract it to these pine plantations.

\section{Eastern Bluebird, Sialia sialis}

Seen rarely and only in recent clearcuts or burns, where it could nest in old woodpecker holes in standing snags. Where snags were left standing after cutting it remained for several years as long as there was open ground where it could forage.

\section{Veery, Catharus fuscescens}

Always occurred in mixed forests where conifers were few to absent. Appeared when forests reached about 10 years of age and continued in relatively low numbers in more mature forest as long as undergrowth remained lush. Deciduous trees could be widely spaced as long as taller shrubs were numerous.

\section{Swainson's Thrush, Catharus ustulatus}

Most numerous in mixed forest where pines dominated, but rare in pine forest. Occurred in either situation where tall shrubbery was present in significant amounts. Began to appear when trees were about 10 years old and was most abundant in 20-year-old woods. Seldom found in taller forest where understorey was often scarce, but usual in dense young stands where conifers and deciduous growth were present and more equal in height. Large areas of tall deciduous shrubs were relatively rare in the older pine forests, so this species was seldom seen there.

\section{Hermit Thrush, Catharus guttatus}

One of the most ubiquitous and characteristic species of pine forests and to a lesser extent of mixed woods. Moved into an area once vegetative cover of any type reached about $3 \mathrm{~m}$ high and seemed to prefer areas with a more open character-either between dense patches of trees and shrubs, or, preferably, where dense tree cover rose above a cover of low shrubs, leaving fairly open space between the low shrubs and lower tree branches. Maximum densities for the species were reached where pines were about 20 years of age. Numbers were lower in more mature mixed forest, probably because deciduous shrubs were usually numerous, but populations remained high in maturing pine forests where tall shrubs were more sparse. 
American Robin, Turdus migratorius

Relatively rare in forested situations. Most numerous in young plantations where there was open ground on which to forage, and, except at the edges, virtually absent in older forests, whether pine or mixed.

\section{Brown Thrasher, Toxostoma rufum}

Never numerous because the study forests are near the northern edge of its range. Very young and open regeneration provided habitat. Associated with open shrubby areas in either forest type.

\section{Cedar Waxwing, Bombycilla cedrorum}

Not censused well because it is a very late nester. Could be heard flying over almost any type or age of stand, but probably nested only in young mixed woods where pincherry provided food.

\section{Solitary Vireo, Vireo solitarius}

Uncommon but characteristic of the jack pine forests, only rarely wandering into adjacent mixed forest. First began to nest when trees reached about $10 \mathrm{~m}$ in height, but was most numerous in mature forests. Nested and foraged where canopy cover was high (more than 75 per cent).

\section{Philadelphia Vireo, Vireo philadelphicus}

Common only in deciduous portions of older mixed forest where trees exceeded $10 \mathrm{~m}$ in height. Showed a strong preference for trembling aspen, but in rare instances white birch formed as many as one-third of the trees in its territories.

\section{Red-eyed Vireo, Vireo olivaceus}

Always required some deciduous trees and was common in groves of pure deciduous trees; wandered on occasion into pine forests from adjacent deciduous areas. First occupied an area when trees reached 3 to $4 \mathrm{~m}$ high, but preferred older forests.

\section{Tennessee Warbler, Vermivora peregrina}

Preferred very open edges of spruce woods. Managed pine forests were generally too dense to attract this species, but a few were recorded where there were openings in the pines and when budworm numbers were high.

\section{Nashville Warbler, Vermivora ruficapilla}

One of the most numerous of birds in managed pine forests and almost as numerous in mixed forests where pines formed at least half the mix. Began to colonize an area when trees were 5 to $6 \mathrm{~m}$ high and reached maximum densities where trees were 10 to $12 \mathrm{~m}$ tall. Trees were relatively uniformly spaced and dense on occupied territories; however, there was typically one opening, and often several, where sunlight reached the forest floor and tall shrubs grew. Where nesting occurred, the ground was typically densely covered with sedges growing among blueberries and sheep laurel.

\section{Yellow Warbler, Dendroica petechia}

Encountered rarely; unlikely to be found except in very young regeneration with a high component of deciduous growth.

\section{Chestnut-sided Warbler, Dendroica pensylvanica}

Associated with deciduous shrubs in mixed regeneration. Appeared when growth was about $3 \mathrm{~m}$ high, became abundant in growth of 6 to $7 \mathrm{~m}$ tall with numerous small shrubs, and persisted in diminishing numbers until tree crowns developed to form a canopy. Few remained once trees reached $10 \mathrm{~m}$ in height in these dense plantations.

\section{Magnolia Warbler, Dendroica magnolia}

Tended to avoid pure pine forests, preferring the edges of mixed forest, but occasionally nested in pine woods of about 15 to 25 years of age where there were openings and some small spruces growing. Occurred commonly in mixed woods of 15 to 30 years old where small spruce and balsam fir were interspersed at edges or openings.

\section{Black-throated Blue Warbler, Dendroica caerulescens} Common only in deciduous forest taller than $16 \mathrm{~m}$ where tall deciduous shrubs covered 50 to 75 per cent of the ground. Pines were usually few to absent, but occasionally were as much as 60 per cent of tree cover.

\section{Yellow-rumped Warbler, Dendroica coronata}

One of the common species in all habitats, but found in mixed forests only where pines were dominant. Began to colonize habitats when pines were about 5 to $6 \mathrm{~m}$ tall and quickly reached maximum densities in trees of about 10 to $12 \mathrm{~m}$ tall. Seemed to prefer slightly open portions of the forest but occurred almost anywhere, including some very dense patches.

\section{Black-throated Green Warbler, Dendroica virens A vagrant; recorded only once.}

\section{Blackburnian Warbler, Dendroica fusca}

A characteristic species of pine forest as well as of mixed forest where pines constituted at least 40 per cent of the tree cover. Did not begin to colonize a stand until pines reached at least $10 \mathrm{~m}$ in height and was never numerous until they exceeded $12 \mathrm{~m}$. Common in the older pine forests, usually where trees were fairly dense and uniform and tall shrubs were few. 
Palm Warbler, Dendroica palmarum

Reported to us on only one occasion in a 20 -year-old pine woods.

\section{Bay-breasted Warbler, Dendroica castanea}

Common in pine forests 40 or more years old only when jack pine budworm was in epidemic proportions; declined and disappeared as the budworm population crashed. Could be found any year in adjacent mixed forest with spruce trees, which it obviously preferred.

\section{Black-and-white Warbler, Mniotilta varia}

Found only rarely in pine forest; one pair nested in a uniform stand of young pines of 8 to $10 \mathrm{~m}$ in height where the ground had a dense cover of blueberries and sheep laurel, and only a relatively sparse growth of taller deciduous shrubs. Usually associated with the deciduous component of mixed forests, where it was uncommon; found in stands of about 20 years old, or at the edges of taller woods where tall shrubs covered most of the ground, below or among taller deciduous trees.

\section{American Redstart, Setophaga ruticilla}

Common in younger mixed woods where deciduous trees and shrubs reached 6 to $7 \mathrm{~m}$ and at least some were in fairly dense groves. Avoided older forests where trees formed a canopy.

\section{Ovenbird, Seiurus aurocapillus}

A common and characteristic species of pine forests from the time trees reached about $10 \mathrm{~m}$ in height; also present in mixed forests once trees were 10 to $12 \mathrm{~m}$ high. The main habitat requirement was a dense canopy cover in most of the territory. Tall shrubs could cover as much as 50 per cent of the ground, but were typically sparse. The ground was usually densely covered with low shrubs and herbs, especially in pine forests. Herb growth in leaf litter was the ground cover more often found in territories in deciduous woods, but bracken would become thick later in the season.

\section{Connecticut Warbler, Oporornis agilis}

Lone males sang for several summers in the 40- to 50year-old pine forest where trees were 12 to $16 \mathrm{~m}$ high. The species has apparently not yet colonized this type of habitat in any numbers in this part of the province.

\section{Mourning Warbler, Oporornis philadelphia}

Uncommon; found where tall deciduous shrubs covered at least 50 per cent and often nearly 100 per cent of the ground. Usually occurred in areas cut or burned five to 10 years previously, but also at the edges of tall pine forest where shrub growth and raspberry canes were common.

\section{Common Yellowthroat, Geothlypis trichas}

Common in regenerating areas where sedges and grasses covered much of the ground and deciduous shrubs covered 25 to 75 per cent of the area. Gradually left an area as trees grew and shaded the ground. Few, if any, remained when trees were 20 years old.

\section{Canada Warbler, Wilsonia canadensis}

Rare; found in only one area of dense deciduous shrubs with moist depressions; not specifically associated with pines.

\section{Scarlet Tanager, Piranga olivacea}

Never numerous because it was near the northern periphery of its range. Associated only with taller deciduous trees in mixed forest.

\section{Rose-breasted Grosbeak, Pheucticus ludovicianus}

Never numerous at this latitude. Associated only with deciduous elements of mixed forests; could be found in more open parts of any mixed forest more than 20 years old.

\section{Chipping Sparrow, Spizella passerina}

Uncommon; a characteristic species of pines, preferring edges and openings only. Began to appear when trees reached about 10 years of age and occurred in all ages thereafter. Probably reached maximum abundance when trees were about 20 years old and there were still numerous openings to ground that was typically covered with low shrubs.

\section{Clay-colored Sparrow, Spizella pallida}

Encountered only once and unlikely to be found in the area, but would be associated with very open areas with pines less than 10 years old.

\section{Vesper Sparrow, Pooecetes gramineus}

Uncommon; found where a ground cover of sedges or grasses was present among well-spaced regenerating pines, with few or no tall shrubs to shade the ground. Gone by the time trees reached 10 years of age.

\section{Song Sparrow, Melospiza melodia}

Rare; not expected except at the edge of a forest, near water, where deciduous shrubbery was present among scattered small pines.

\section{Lincoln's Sparrow, Melospiza lincolnii}

Rare; found only in areas where pines were small and well spaced and where sedges, grasses, and scattered deciduous shrubs formed some ground cover. No longer present where pines had grown beyond about 15 years of age. 
White-throated Sparrow, Zonotrichia albicollis

One of the most ubiquitous of species in both pine and mixed forest; essentially a bird of shrub growth, whether in early regeneration or at the edges and openings of older forests. Would move into an area as soon as deciduous shrubs reached about $1 \mathrm{~m}$ in height, provided they covered at least 50 per cent of the ground. Abundant where pines were less than 10 years old; decreasing in numbers in successively older stands as the canopy closed.

\section{Dark-eyed Junco, Junco hyemalis}

Common; a characteristic species of pine forests. First occurred in pine woods when trees were 10 years of age and was at maximum densities when trees were about 20 years of age. Avoided deciduous forest and to a lesser extent mixed forest as well. Territories occupied forests that were very uniform with a continuous canopy or where only small openings and gaps were present. Tall deciduous shrubs were sparse to absent wherever juncos occurred, although low shrubs were numerous as usual in all the Gogama study forests.

\section{Rusty Blackbird, Euphagus carolinus}

Rare; wandered into young woods from adjacent wet areas.

\section{Common Grackle, Quiscalus quiscula}

Rare; wandered into young woods from adjacent wet areas.

\section{Purple Finch, Carpodacus purpureus}

Present in small numbers in every year and in most ages and mixes of forest but never seemed to be resident there. Although it might be expected to nest in any pines in excess of 10 years of age, here it seemed to be just foraging.

\section{Crossbill sp., Loxia sp.}

Both Red Crossbill and White-winged Crossbill were numerous in pine forests when jack pine budworm was abundant, but neither remained once budworm was gone.

\section{American Goldfinch, Carduelis tristis}

Seldom ever seen in the area at any time. Visited young mixed woods on rare occasions.

\section{Evening Grosbeak, Coccothraustes vespertinus}

Uncommon every year, but usually heard flying overhead. Not censused well and no strong habitat affinity was identified. Could be feeding in any pine or mixed forest in excess of 10 years of age, but would not likely nest except in mature trees.

\section{Discussion}

Erskine's (1977) summary of census data relating to bird populations in boreal forests, including jack pine habitats, remains a very valuable contribution to the study of northern bird communities, and is the only major work against which our more local data set can be compared and contrasted. Although our findings should have some applicability to jack pine forests elsewhere in Canada, we cannot accurately predict the situation in other distant but similar pine forests where climatic, site, and shrubby vegetation conditions could be considerably different from those of the study area in Gogama.

Erskine derived population estimates using the spotmapping method (International Bird Census Committee, 1970), whereas we used transect counts. The results might therefore be expected to differ somewhat. The accuracy of transect methods in deriving population estimates has been criticized, but so has that of the best available alternative, the spot-mapping method (Svensson, 1974; Best, 1975, 1981; Oelke, 1981). While the search continues for an accurate census method, transect counts allow for a much more efficient sampling, and, given the variation inherent in any sampling method (Verner, 1985), they are an appropriate means of deriving population estimates (Emlen, 1977; Christman, 1984).
While spot-mapping calls for eight or more visits to a plot through an entire breeding season, we attempted to confine our counts in any one habitat to a short period of time. This provided a "snapshot" of the species present at one period of time and minimized a bias resulting from birds that would inevitably wander into or out of an area over a more prolonged period.

The short sample period we used introduces some bias because early-nesting species (e.g., Boreal Chickadee, Hermit Thrush, Dark-eyed Junco, and White-throated Sparrow) could be considerably quieter once they were sitting on eggs, and later-nesting species (e.g., Cedar Waxwing) could te unsettled. However, we followed the same procedure each year so that results would be as comparable as possible. And given that early or late nesters were not sampled at optimal times, our counts are probably low. We counted birds beginning in late May, as soon as it was apparent that even late arrivals were on territory.

The transect method used, while it cannot adequately sample all species, is most suited to songbirds, which form the largest component of the forest avifauna. We feel that no passerine was missed. Some species however, particularly some finches (Purple Finch, crossbills, and 
Evening Grosbeak), because of their habits, were not sampled accurately, but they formed a relatively small component of the avifauna in non-budworm years.

\section{THE PINE FOREST}

In the Gogama area, in the first few years following the planting of jack pines, where deciduous growth (other than low shrubs and herbaceous growth) was limited, associated bird species were those attracted primarily by an open habitat rather than by the pines.

Species to be expected included Red-tailed Hawk, Northern Harrier, American Kestrel, American Crow, Common Raven, Northern Flicker, Eastern Bluebird, and Vesper Sparrow. A few Brown Thrasher and Rubythroated Hummingbird were regular; Song Sparrow and Yellow Warbler were not expected. Northern Flicker provided cavities in adjacent snags that subsequently attracted American Kestrel and Tree Swallow.

Vesper Sparrow and Eastern Bluebird can occupy such areas for only five or six years, after sparse vegetation becomes established but before tree growth becomes too dense for their liking. The other species mentioned may use such areas for as long as 10 to 15 years in gradually diminishing numbers, as long as there are openings sufficient for foraging.

The most abundant species, the White-throated Sparrow, is among the first to colonize once ground cover becomes well established and trees exceed about $1 \mathrm{~m}$ in height. It is also the only species that persists through all ages of the maturing forest wherever edges and openings are found.

When pines reached 10 to 15 years of age, most of the species that formed the core of the pine forest community-Yellow-bellied Flycatcher, Boreal Chickadee. Hermit Thrush, Nashville Warbler, Yellow-rumped Warbler, Ovenbird, Chipping Sparrow, and Dark-eyed Junco-had moved in and established themselves. All of these species reached their highest densities in forests of about 20 to 25 years of age. Spruce Grouse had also become established at a high density (Szuba and Bendell, 1983). These species all persisted as forests matured, so that even at 20 years of age the pine forest had almost the full complement of species that would remain as the forest matured.

Three additional species of importance were Solitary Vireo, Blackburnian Warbler, and, where some spruces were present, Golden-crowned Kinglet. These began to appear only when trees were about 20 years old and reached maximum numbers by the time the forest was 40 years old

Northern Goshawk was hunting in forests by the time trees were 20 years of age (radio-tagged grouse were taken), and would remain as forests matured. Sharpshinned Hawk was seen and certainly would also be hunt- ing for small birds in wooded areas of between 20 to 60 years of age. When budworm numbers were high, Tennessee Warbler and crossbills were attracted to forests of more than 20 years of age. Bay-breasted Warbler occurred in very high numbers during the peak of a budworm outbreak, but only in forests of about 40 or more years old. Evening Grosbeak and to a lesser extent Purple Finch fairly regularly also frequented pine forests of any age above 20 years, but seemed to make somewhat limited use of the pines, except when budworm was abundant.

Several other species that we know have nested, or that easily could nest, in pine woods and are likely to do so on occasion include Brown Creeper, Red-breasted Nuthatch, Swainson's Thrush, American Robin, Rubycrowned Kinglet, Magnolia Warbler, Black-and-white Warbler, and Connecticut Warbler. Of these, only Redbreasted Nuthatch, Brown Creeper, and Connecticut Warbler are likely to make extensive use specifically of pine forests in this district. The nuthatch and creeper, however, are limited by nest-site availability, and the warbler is at the edge of its range here and still rare.

Any of the other species that were found in pine forests more than 20 years old (Alder Flycatcher, Gray Jay, Blue Jay, Black-capped Chickadee, Veery, Cedar Waxwing, Red-eyed Vireo, Chestnut-sided Warbler, Palm Warbler, American Redstart, Common Yellowthroat, and Lincoln's Sparrow) tended only to be wandering through or making very limited use of pines, or were attracted by vegetation other than pines.

Several differences are notable between our counts in managed forests (greater than 20 years of age) and those presented by Erskine (1977). Erskine considered Rubycrowned Kinglet as a characteristic species, while we seldom ever encountered it. Differences probably in canopy cover and certainly in tree-species composition would account for the conflicting results. Canopy cover averaged only 20 to 30 per cent on the stands Erskine studied, while our stands had in excess of 60 per cent canopy cover. The spruce swamps found in wetter areas adjacent to some of the pine forests in our area were the usual haunts of Ruby-crowned Kinglet and had more open canopies than the pines. Ruby-crowned Kinglet seems heavily reliant on spruces (Peck and James, 1987; personal experience), and where this species occurred in the pine forests, some spruce trees were usually present. Erskine also considered Swainson's Thrush, American Robin, and Tennessee Warbler to be frequent inhabitants of jack pine, whereas we found them scarce to absent. The reason for this difference might be the more open nature (and associated tall shrub growth) of the stands considered by Erskine (1977).

Erskine (1977) considered only five species as found in most jack pine stands (Hermit Thrush, Ruby-crowned Kinglet, Yellow-rumped Warbler, Dark-eyed Junco, and 
White-throated Sparrow). We found eight more species virtually always present and forming an important component of the avifauna in managed pine forests: Spruce Grouse, Yellow-bellied Flycatcher, Boreal Chickadee, Solitary Vireo, Nashville Warbler, Blackburnian Warbler, Ovenbird, and Chipping Sparrow. Although Solitary Vireo, Nashville Warbler, and Chipping Sparrow were mentioned as frequent by Erskine, others were not specifically mentioned, and Blackburnian Warbler was not even listed as occurring in jack pine forests.

Spruce Grouse is not censused well by spot-mapping or transect counts and therefore did not register more than present in either study, but other work in the Gogama area clearly showed this species to be numerous in jack pines (Szuba and Bendell, 1983). It may just have been overlooked in censuses done elsewhere, but in more open pine forests it may well have been scarce to absent.

The increased canopy cover of the managed forests would certainly be more attractive to Yellow-bellied Flycatcher, Boreal Chickadee, Solitary Vireo, Ovenbird, and probably also Nashville Warbler and Blackburnian Warbler. Although there have been few censuses in jack pine stands in boreal and near-boreal areas of eastern North America, the recorded absence of Blackburnian Warbler in such stands (Erskine, 1977) was surprising compared to the numbers we found. Erskine's censuses in the Quebec Clay Belt (Erskine, 1970) and near Matheson, Ontario (Erskine, 1971), were at a somewhat more northerly latitude than our study area $\left(48^{\circ} 26^{\prime}\right.$ and $48^{\circ} 32^{\prime}$ $\mathrm{N}$ vs. $47^{\circ} 28^{\prime} \mathrm{N}$ ), but they were not beyond the range of Blackburnian Warbler (Cadman, Eagles, and Helleiner, 1987). Blackburnian Warbler has been recorded in jack pine stands somewhat farther south and less boreal $\left(48^{\circ}\right.$ $08^{\prime} \mathrm{N}$ ) in northern Minnesota (Niemi, 1974). While this species has been linked with fir, hemlock, and other types of pine forest, it must also be considered a dominant member of at least denser stands of jack pine in southern boreal areas of central Ontario. We found Blackburnian
Warbler consistently, even in the absence of budworm, in our area.

The overall density figures that we recorded in managed jack pine forests (even after budworm was no longer attracting large numbers of Bay-breasted Warbler) were about double the density reported by Erskine (1977) in jack pines. Also, despite some differences in census techniques, which could result in somewhat higher totals by our method, several species in the managed forests appear to occur in notably higher numbers than reported in jack pine by Erskine (1977; see Table 10). Our mean density figures for Hermit Thrush are two to three times higher, and for Yellow-rumped Warbler three to four times higher. Even more remarkable are Nashville Warbler and Yellow-bellied Flycatcher, more than 10 times higher, and Ovenbird, more than 16 times higher, than densities given by Erskine (1977). Boreal Chickadee also appeared much more numerous (and consistent) than recorded by Erskine, but was still at relatively low numbers. Our census totals in managed jack pines are similar to those given by Erskine (1977) for typical boreal spruce forest.

Such differences are no doubt accounted for in part by the increased tree density (and uniformity) of the forests we studied, which provided increased canopy cover and higher foliage volume. The number of trees per hectare and the basal area values for five stands given by Erskine (1977) are about half of those in P-2 and P-3 at Gogama, resulting in our higher canopy-cover values. In the Gogama forests the layer of low shrubs covering virtually 100 per cent of the ground is probably also important. Erskine (1977) had ground covers of only 40 to 50 per cent in the Clay Belt areas. The low shrubs in the Gogama forests would be particularly attractive to Hermit Thrush, Nashville Warbler, and Ovenbird. The increased numbers of these three species, plus the presence of Blackburnian Warbler, would easily account for the differences between our results and the estimates provided by Erskine (1977).

TABLE 10. Comparison of mean density values (males or pairs $/ \mathrm{km}^{2}$ ) for selected jack pine-inhabiting bird species in the area studied by Erskine (1977) and areas P-2 and P-3 of the present study.

\begin{tabular}{llll}
\hline & Erskine (1977) & P-2 & P-3 \\
\hline Yellow-bellied Flycatcher & 1 & 14 & 10 \\
Hermit Thrush & 15 & 41 & 26 \\
Nashville Warbler & 4 & 65 & 41 \\
Yellow-rumped Warbler & 15 & 60 & 42 \\
Ovenbird & 2 & 33 & 73 \\
\hline
\end{tabular}




\section{THE MIXED PINE/DECIDUOUS FOREST}

Recently cut or burned areas that, although planted with pines, would produce nearly equal numbers of deciduous trees and numerous deciduous shrubs, attracted the same bird species as areas newly planted to pines. However, birds had fewer years to use the new mixed area before shrub growth rendered it largely unsuitable for these open-country species.

Within five years shrub growth and ground cover provided for two principal species, Common Yellowthroat and White-throated Sparrow, and for fewer numbers of Lincoln's Sparrow and Mourning Warbler (Table 5). Alder Flycatcher also was beginning to become very numerous in the shrub growth. By this time open-country species were virtually gone.

Between five and 10 years, as vegetation reached above $3 \mathrm{~m}$ in height and became more dense, many more species began to appear (Ruffed Grouse, Blue Jay, Veery, Hermit Thrush, American Robin, Cedar Waxwing, Redeyed Vireo, Nashville Warbler, Chestnut-sided Warbler, Yellow-rumped Warbler, and Dark-eyed Junco). Additional species appeared between 10 and 20 years (including Yellow-bellied Flycatcher, Black-capped Chickadee, Swainson's Thrush, Magnolia Warbler, Black-and-white Warbler, American Redstart, Rosebreasted Grosbeak, and Chipping Sparrow), and those that were so abundant at 10 years of age were largely gone. Most of the species that colonized between 10 and 20 years of age would also remain as the forest matured.

Half of the species were attracted to the dense growth of deciduous shrubs and young deciduous trees, and most of the rest used both pines and deciduous growth. The species with the highest densities were those using specifically deciduous growth (Alder Flycatcher, Veery, Redeyed Vireo, Chestnut-sided Warbler, Black-and-white Warbler, American Redstart, and Rose-breasted Grosbeak) or those that reach highest densities where deciduous growth occurs with pines (American Robin, Magnolia Warbler, and White-throated Sparrow). The combination of species attracted by tall shrubs as well as those attracted by mixed tree growth produced the highest density figures recorded for any habitat.

Meanwhile, many of the species that occurred in pure pines were present in mixed habitats, but some were well below levels recorded in pines (Yellow-bellied Flycatcher, Yellow-rumped Warbler, Chipping Sparrow, and Dark-eyed Junco; Tables 3 and 7) while others were no more abundant (Hermit Thrush and Nashville Warbler), indicating that mixed forest was not as favourable a habitat for most of them.

By the time a mixed habitat reached 40 years of age many of the early-successional shrub dwellers had departed (Alder Flycatcher, Chestnut-sided Warbler, American Redstart, Mourning Warbler, Common Yellowthroat, and
Lincoln's Sparrow) or were present only in low numbers (Black-and-white Warbler, Magnolia Warbler, and Swainson's Thrush). Meanwhile, a new suite of species had taken up residence. These were associated with deciduous trees (Least Flycatcher, Philadelphia Vireo, and Scarlet Tanager) or with deciduous shrubs below a tree canopy (Black-throated Blue Warbler), or were those appearing in medium-aged or older pine forests (Blackburnian Warbler, and, in low numbers, Goldencrowned Kinglet and Solitary Vireo).

The absence of numbers of shrub dwellers in mediumaged mixed forests dramatically lowered the species totals. The addition of some more deciduous-inhabiting species did not compensate for the departure of the earlysuccessional species. In addition, some of those species associated specifically with pines had declined much farther (Hermit Thrush, Nashville Warbler, and Yellowrumped Warbler), or had been virtually eliminated (Darkeyed Junco and Chipping Sparrow). Thus, the mixed forest, while attracting a somewhat higher diversity of species than the pine forest because of the combination of deciduous and coniferous components, had bird densities that were only comparable to those of the pine forest (Tables 5 and 9). The increased diversity did not result in increased density.

\section{PINE FOREST VS. MIXED FOREST}

Recently planted and regenerating areas were likely to be visited by similar suites of bird species, regardless of the forest cover in later years. The main difference between pine and mixed forest was that, where mixed growth dominated, the very early-successional bird species had fewer years to take advantage of the open spaces between trees.

In young woods of about 20 years of age, however, notable differences were apparent between plantations composed almost entirely of jack pine and areas where pines were mixed among deciduous trees and shrubs. If we exclude the casually occurring species, 20-year-old pine stands regularly had 10 to 12 species, nine or 10 of which made up the bulk of the population, whereas similarly aged mixed woods normally had 20 or 21 species, 13 to 15 of which made up the bulk of the population. Pines hosted Spruce Grouse and Boreal Chickadee, whereas mixed stands had Ruffed Grouse and Blackcapped Chickadee. In pines, Alder Flycatcher, Vcery, Swainson's Thrush, Red-eyed Vireo, Blue Jay, Chestnutsided Warbler, American Robin. Magnolia Warbler, Black-and-white Warbler, and American Redstart were few to absent, but these were numerous in mixed stands. Conversely, Yellow-bellied Flycatcher, Ovenbird, Darkeyed Junco, and Chipping Sparrow were numerous in pines but much rarer in mixed areas. Nasluville Warbler. 
Yellow-rumped Warbler, and White-throated Sparrow occurred in nearly equal numbers in either habitat. The mixed areas hosted about twice the number of species as well as twice the density of birds as the young pine woods.

In medium-aged forests the differences between pine and mixed remained pronounced, although a number of different species were involved. The pines hosted Spruce Grouse, Boreal Chickadee, Yellow-bellied Flycatcher, Hermit Thrush, and Solitary Vireo, while mixed areas had Ruffed Grouse, Black-capped Chickadee, Least Flycatcher, Veery, Swainson's Thrush, Red-eyed Vireo, and Philadelphia Vireo. The pines also had Yellowrumped Warbler, Nashville Warbler, Chipping Sparrow, Dark-eyed Junco, and White-throated Sparrow, while the mixed forests usually had few or none of these. And the mixed areas had Black-throated Blue Warbler, Scarlet Tanager, Black-and-white Warbler, Rose-breasted Grosbeak, and Magnolia Warbler, whereas the pines usually had none of these species. Common to both types of forest and in similar numbers were only two species, Blackburnian Warbler and Ovenbird.

In medium-aged forests pine regularly hosted 13 to 16 species (slightly more than at 20 years of age) with eight to 10 of these forming the bulk of the population, and mixed regularly hosted 17 to 22 species, with only six to nine of them forming the bulk of the population. Populations in pure pine and mixed were about equal, although the mixed forests had a greater diversity of species. But the species complement of the two areas was very different. Unless both types of habitat were present, many species could not find appropriate nesting habitat.

Notable in both types of actively managed forest was the relative absence of cavity-nesting species. This can be attributed largely to the absence of snags (flattened before planting) and larger older trees that in a natural forest might be dead or dying and thus suitable for excavation by cavity nesters.

\section{POPULATION CHANGES}

Very young pine stands had comparatively few birds (about $140 \mathrm{pr} / \mathrm{km}^{2}$ in P-1). Numbers increased to somewhat in excess of $300 \mathrm{pr} / \mathrm{km}^{2}$ by the time stands were 20 years old and showed no apparent change from that over the seven years of the study, although there was considerable fluctuation (mean $335 \mathrm{pr} / \mathrm{km}^{2}$ in P-2).

In stands younger than about 40 years of age, changes in the numbers of any species over several years were likely to be the result of successional changes in the habitat. In the older forests, however, changes might indicate a changing abundance as a result of some other factor. In the medium-aged pine forest (P-3; Table 5) with the longest data set, there were notable changes in the first few years for several species, which showed large declines: Bay-breasted Warbler and Yellow-rumped Warbler from 1985 to 1986, and Ovenbird and Nashville Warbler from 1986 to 1987. However, those declines were not sustained in subsequent years. The previous larger numbers were likely due to the increased presence of budworm, either attracting nesting pairs or possibly increasing the numbers of offspring present in a subsequent year. From 1987 to 1992 no species showed an obvious downward trend. There is some evidence of a downward trend for Chipping Sparrow from 1987 to 1992, but this could still be due to successional change. A longer-term data set would be better able to distinguish population trends from short-term fluctuations.

When the pine forest reached 40 to 50 years of age average numbers appeared to decline only slightly from those in 20-year-old forest. In 1985 the population in P-3 was high $\left(624 \mathrm{pr} / \mathrm{km}^{2}\right)$ because of an outbreak of budworm, and declined markedly over the next two years. In the last six years of censusing, the population fluctuated around $300 \mathrm{pr} / \mathrm{km}^{2}$ (mean $316 \mathrm{pr} / \mathrm{km}^{2}$ ) It seems that a population slightly in excess of $300 \mathrm{pr} / \mathrm{km}^{2}$ would likely be maintained until the forest becomes mature to overmature, at which time openings and dying trees would probably attract more species and possibly increase population levels somewhat.

Bird populations in areas of mixed growth no doubt have a higher complement of species sooner than pure pines because of shrub growth. In a six-year-old mixed area numbers of birds equalled or exceeded those of a 20year-old pine plantation. In the mixed woods, numbers climbed until reaching more than $1000 \mathrm{pr} / \mathrm{km}^{2}$ by 20 years of age. From 20 to 40 years of age the numbers for mixed woods declined again and appeared to be about the same as pine forests at 40 years of age. Those levels were likely to be maintained until forests matured when population levels might increase slightly again.

\section{FORESTRY}

The diet of insectivorous birds may be more than 80 per cent destructive forest insects (Takekawa, Garton, and Langelier, 1982). It has been proven that birds significantly reduce the numbers of insects in forests (Holmes, Schultz, and Nothnagle, 1979; Mattson et al, 1968; Takekawa, Garton, and Langelier, 1982). Birds may not be able to exert much influence in controlling some insects such as budworm once it has reached epidemic proportions, but they may do a great deal to keep insects at endemic levels (Kendeigh, 1947; Otvos, 1979; Thomas et al., 1979; Takekawa, Garton, and Langelier, 1982). It would seem, then, to be in the best interests of forestry to do whatever is possible through forestry practices to encourage birds to use the planted forests and to maintain 
population levels at least as high as those found in naturally occurring forests.

The relatively uniformly aged and dispersed jack pine forests that result from planting following clearcutting are obviously relatively good environments for certain species of birds, and several species occur in densities as high or higher than recorded elsewhere in boreal jack pine forests or even boreal spruce forest. However, the number of species able to make extensive use of pure jack pine plantations is somewhat limited. Especially at younger ages, the mixed woods attract many more and different species (although they also include at least a few of the pine forest inhabitants). The mixed forests (or predominantly deciduous forests) provide an essential habitat for some species that do not occur in pine forests. The lack of deciduous vegetation in managed pine forests (through herbicide treatment) is particularly critical in the five to 20 years following planting. Many early-successional bird species rely on deciduous growth. Populations of these species also tend to be high in the few years available through the total rotation time of the forest.

The uniform nature of the managed pine forests also tends to limit certain species. Golden-crowned Kinglet, for example, occurs only where some spruce has regenerated among the pines. This branch-tip forager could be very important in budworm suppression, and its population could be considerably enhanced through the inclusion of a small percentage of spruce in a planting. Spruce Grouse is also frequently encountered where spruce occurs within pine forest. Spruce provides the grouse as well as other species with much better winter cover.

Species that like a dispersion of small openings in the canopy of the forest (Ruby-crowned Kinglet and Chipping Sparrow) are also no doubt less populous than they might be if forests were less uniform. However, neither is rare in any event.

Perhaps the one forestry practice that has the most severe impact is the knocking down of snags before planting. It is known that nest-site scarcity can limit hole-nesting birds (Dickson, Conner, and Williamson, 1983; Zarnowitz and Manuwal, 1985). Woodpeckers were encountered regularly only in $\mathrm{M}-2$, the young mixed woods, where a number of birch snags had been left standing. With the exception of chickadees, which were rather rare although regular, primary cavity nesters were virtually absent in medium-aged pine forests. Without the primary excavators, secondary cavity users were also almost totally absent, as were creepers. The cavity nesters are, in large part, year-round residents and could have a significant impact on insect populations through the period of the year when insects are inactive or present in relatively small numbers.

The short rotation time in intensively managed forests also eliminates Pileated Woodpecker, which requires trees in excess of $55 \mathrm{~cm}$ DBH to meet its preferred nesting requirements (Conner, 1979) and numerous snags to supply its food needs. Intensively managed patches of forest provide almost no place for any cavity nester.

Leaving snags and a few scattered live trees (especially deciduous) standing, and providing a small proportion of deciduous trees within pine forests for future snags would help to encourage the cavity nesters. In addition to snags, the dying deciduous trees would create some openings. These would attract other insectivorous species, such as Nashville Warbler, Chipping Sparrow, and White-throated Sparrow, which would further enhance insect suppression. 


\section{Conclusions}

Managed uniform-aged jack pine forests in the Gogama area included the following:

1. Good breeding habitat for eight to 11 bird species (Spruce Grouse, Yellow-bellied Flycatcher, Hermit Thrush, Nashville Warbler, Yellow-rumped Warbler, Ovenbird, Chipping Sparrow, Dark-eyed Junco, plus Golden-crowned Kinglet, Solitary Vireo, and Blackburnian Warbler as forests mature)

2. High numbers of five passerine species (Yellow-bellied Flycatcher, Hermit Thrush, Nashville Warbler, Yellow-rumped Warbler, and Ovenbird)

3. Casual and intermittent habitat for an additional 12 to 18 species

4. Large numbers of Bay-breasted Warbler and substantial numbers of Evening Grosbeak and crossbill species during budworm outbreaks

5. Population densities of birds comparable to those normally found in boreal spruce forests ( 200 to $400 \mathrm{pr} / \mathrm{km}^{2}$ )

6. Low numbers of only one cavity-nesting species (Boreal Chickadee)

Uniform-aged mixed forests in the Gogama area included the following:

1. When young (about 20 years old), twice the number of species (20 to 21 ) and population densities two to three times higher than those found in pine forests of similar age
2. When older, slightly higher numbers of species ( 13 to 16) than, but densities only about equal to, those found in similarly aged pines

3. Casual or intermittent habitat for an additional 12 to 16 species

4. Habitat attractive to many species not found at all in pine forests, and only low numbers of most species that typically form the core population in pine forests

5. When younger, habitat usable by many early-successional species that may not occupy young pine woods

6. Low numbers of only one cavity-nesting species (Black-capped Chickadee), except where snags were left standing

Pine forests, before they reached 20 years of age, had already attracted most of the species that would form the bulk of the bird population at any age thereafter. Mixed forests had a more noticeable and continuous change in species composition until the forest was close to 40 years of age.

Cavity-nesting species were scarce in either type of forest. Providing even 5 per cent deciduous trees in pine forests and/or leaving 2 to 5 per cent deciduous trees standing during harvest would ensure nesting sites for cavity nesters, thereby increasing their populations.

There were no apparent trends in overall populations of birds over the eight-year period of the study in medium-aged pine forest. 


\section{Acknowledgements}

Fieldwork was supported by the Royal Ontario Museum. We thank the E. B. Eddy Company for allowing us to undertake these studies in forests planted and managed by them; Dr. J. F. Bendell for his assistance and encouragement during the study; G. B. Murphy for assistance in the field; K. Szuba and B. Naylor for observations and assistance in the field; the photography department of the Royal Ontario Museum for preparation of the illustra- tions; and the Ontario Ministry of Natural Resources for providing Forest Resource Inventory maps and allowing us to occupy a temporary campsite on Makwa Lake. We are most appreciative of comments made by Dr. D. A. Welsh and Dr. A. J. Erskine on an earlier draft of this manuscript, and of the assistance of Cathy Ayley in manuscript preparation. 


\section{Literature Cited}

AMERICAN ORNITHOLOGISTS' UNION

1983 Check-list of North American birds, 6th ed. Washington, D.C., American Ornithologists' Union. 877 pp.

BALDA, R. P.

1969 Foliage use by birds of the oak-juniper woodland and ponderosa pine forest in southeastern Arizona. Condor 71:399-412.

BEST, L. B.

1975 Interpretational errors in the "mapping method" as a census technique. Auk 92:452-460.

1981 Seasonal changes in detection of individual bird species. In Ralph, J. C., and J. M. Scott, eds., Estimating numbers of terrestrial birds. Studies in Avian Biology 6. Lawrence, Kansas, Cooper Ornithological Society, pp. 252-261.

CADMAN, M. D.. P. F. J. EAGLES, and F. M. HELLEINER, comps.

1987 Atlas of the breeding birds of Ontario. Waterloo, University of Waterloo Press. 617 pp.

CHRISTMAN, S. P.

1984 Plot mapping: Estimating densities of breeding bird territories by combining spot mapping and transect techniques. Condor 86:237-241.

CONNER, R. N.

1979 Minimum standards and forest wildlife management. Wildlife Society Bulletin 7:293-296.

COTTAM, G., and J. CURTIS

1956 The use of distance measures in phytosociological sampling. Ecology 37:451-460.

DICKSON, J. G., R. N. CONNER, and J. H. WILLIAMSON

1983 Snag retention increases bird use a of clear-cut. Journal of Wildlife Management 47:799-804.

EMLEN, J. T.

1971 Population densities of birds derived from transect counts. Auk 88:323-342.

1977 Estimating breeding season bird densities from transect counts. Auk 94:455-468.

ENGEL-WILSON, R. W., A. K. WEBB, K. V. ROSENBERG,

R. D. OHMART, and B. W. ANDERSON.

1981 Avian censusing with the strip method: A computer simulation. In Ralph, C. J., and J. M. Scott, eds., Estimating numbers of terrestrial birds. Studies in Avian Biology 6. Lawrence, Kansas, Cooper Ornithological Society, pp. 445-449.

ENGSTROM, T.

1981 The species-area relationship in spot-map censusing. In Ralph, C. J., and J. M. Scott, eds., Estimating numbers of terrestrial birds. Studies in Avian Biology 6 .
Lawrence, Kansas, Cooper Ornithological Society, pp. $421-425$.

ERSKINE, A. J.

1970 Mixed jack pine forest. In Loery, G., ed., Thirtyfourth breeding-bird census. Audubon Field Notes 24:751-752.

1971 Mature jack pine forest. In Van Velzen, W. T., ed., Thirty-fifth breeding-bird census. American Birds 25:986-987.

1977 Birds in Boreal Canada. Canadian Wildlife Service, Report Series 41. 71 pp.

GALLOWAY, R. L.

1984 Jack pine regeneration in the northern region. In Smith, C. R., and G. Brown, eds., Jack Pine Symposium. Canada-Ontario Joint Forestry Research Committee Symposium Proceedings O-P-12. pp. 173-176.

GILLESPIE, W. L., and S. C. KENDEIGH

1982 Breeding bird populations in northern Manitoba. Canadian Field-Naturalist 96:272-281.

GLEASON, H. A., and A. CRONQUIST

1963 Manual of vascular plants of northeastern United States and adjacent Canada. Princeton, Van Nostrand. $810 \mathrm{pp}$.

HOLMES, R. T., J. C. SCHULTZ, and P. NOTHNAGLE

1979 Bird predation on forest insects: An exclosure experiment. Science 206:462-463

HOWSE, G. M.

1984 Insect pests of jack pine: biology, damage and control. In Smith, C. R., and G. Brown, eds., Jack Pine Symposium. Canada-Ontario Joint Research Committee Symposium Proceedings O-P-12, pp. 131-138.

INTERNATIONAL BIRD CENSUS COMMITTEE

1970 An international standard for a mapping method in bird census work recommended by the International Bird Census Committee. Audubon Field Notes 24:722-726.

JAMES, F. C., and H. H. SHUGART, JR.

1970 A quantitative method of habitat description. Audubon Field Notes 24:727-736.

KENDEIGH, S. C.

1947 Bird population studies in the coniferous forest biome during a spruce budworm outbreak. Ontario Department of Lands and Forests, Biological Bulletin $1: 1-100$. 
MCLEOD. J. M.

1967 The effect of phosphamidon on bird populations in jack pine stands in Quebec. Canadian Field-Naturalist $81: 102-106$.

MACLEOD, L. S., V. JANSONS, and A. J. KEIZER

1987 Results of forest insect and disease surveys in the northeastern region of Ontario, 1986. Great Lakes Forest Research Centre, Miscellaneous Report No. 50. 46 pp.

MACLEOD, L. S., V. JANSONS, and S. PAYNE

1988 Results of forest insect and disease surveys in the northern region of Ontario, 1987. Great Lakes Forest Research Centre, Miscellaneous Report No. 78. 37 pp.

1989 Results of forest insect and disease surveys in the northern region of Ontario, 1988. Great Lakes Forest Research Centre, Miscellaneous Report No. 82. 38 pp.

MACLEOD, L. S., C. G. JONES, and A. J. KEIZER

1985 Results of forest insect and disease surveys in the northern region of Ontario, 1984. Great Lakes Forest Research Centre, Miscellaneous Report No. 19. 51 pp.

1986 Results of forest insect and disease surveys in the northern region of Ontario, 1985. Great Lakes Forest Research Centre, Miscellaneous Report No. 38.45 pp.

MATTSON. W. J., F. B. KNIGHT, D. C. ALLEN, and J. L. FOLTS

1968 Vertebrate predation on the jack-pine budworm in Michigan. Journal of Economic Entomology $61: 229-234$.

MOORE, W. S.

1984 Status and potential of jack pine in Ontario. In Smith, C. R., and G. Brown, eds., Jack Pine Symposium. Canada-Ontario Joint Forestry Research Committee Symposium Proceedings O-P-12, pp. 1-8.

NIEMI, G. J.

1974 Mature jack pine forest. In Van Velzen, W. T., ed., Thirty-eighth breeding bird census. American Birds $28: 1016-1017$

OELKE, H.

1981 Limitations of the mapping method. In Ralph, C. J., and J. M. Scott, eds., Estimating numbers of terrestrial birds. Studies in Avian Biology 6. Lawrence, Kansas, Cooper Ornithological Society, pp. 114-118.

OTVOS, I. S.

1979 The effects of insectivorous bird activities in forest ecosystems: An cvaluation. In Dickson, J. G., R. N. Conner, R. R. Fleet, J. A. Jackson, and J. C. Kroll, eds., The role of insectivorous birds in forest ecosystems. New York, Academic Press, pp. 341-374.

PECK, G. K., and R. D. JAMES

1983 Breeding birds of Ontario: Nidiology and distribution. Volume 1: Nonpasscrines. Life Sciences Misccl- laneous Publications. Toronto, Royal Ontario Museum. $321 \mathrm{pp}$.

1987 Breeding birds of Ontario: Nidiology and distribution. Volume 2: Passerines. Life Sciences Miscellaneous Publications. Toronto, Royal Ontario Museum. 387 pp.

ROBBINS, C. S., D. K. DAWSON, and B. A. DOWELL

1989 Habitat area requirements of breeding forest birds of the middle Atlantic states. Wildlife Monograph 103:1-34.

ROWE, J.S.

1959 Forest regions of Canada. Canada Department of Northern Affairs and Natural Resources, Forestry Branch, Bulletin 123.71 pp.

SVENSSON, S.

1974 Interpersonal variation in species map evaluation in bird census work with the mapping method. Acta Ornithologica 14:322-338.

SZUBA, K. J., and J. F. BENDELL

1983 Population densities and habitats of Spruce Grouse in Ontario. In Wein, R. W., R. R. Riewe, and I. R. Methven, eds. Resources and dynamics of the Boreal Zone. Ottawa, Association of Canadian Universities for Northern Studies, pp. 199-213.

TAKEKAWA, J. Y., E. O. GARTON, and L. A. LANGELIER

1982 Biological control of forest insect outbreaks: The use of avian predators. Transactions of the North American Wildlife and Natural Resources Conference 47:393-409.

TERBORGH, J.

1989 Where have all the birds gone? Essays on the biology and conservation of birds that migrate to the American tropics. Princeton, Princeton University Press. 207 pp.

THOMAS, J. W., R. C. ANDERSON, C. MASER, and E. L. BULL

1979 Snags. In Thomas, K. W., ed., Wildlife habitats in managed forests: The Blue Mountains of Oregon and Washington. United States Dept. of Agriculture, Forest Service, Agricultural Handbook 553, pp. $60-77$.

VERNER, J.

1985 Assessment of counting techniques. Current Ornithology 2:247-302.

ZARNOWITZ, J. E., and D. A. MANUWAL

1985 The effects of forest management on cavity-nesting birds in northwestern Washington. Journal of Wildlife Management 49:255-263. 



\section{ROYAL ONTARIO MUSEUM LIFE SCIENCES PUBLICATIONS INSTRUCTIONS TO AUTHORS}

Authors should prepare their manuscripts carefully according to the following instructions; failure to do so will result in the manuscript's being returned to the author for revision. All manuscripts are considered on the understanding that they are not currently offered for publication elsewhere.

1. General Papers for publication are accepted from ROM staff members and research associates, and from researchers reporting on work done with ROM collections. Monographs on the flora and/or fauna of Ontario by authors not affiliated with the ROM may be considered for publication. Financial contributions towards publication may be required. Authors are expected to write clearly and concisely and to omit any material not essential for an understanding of the main theme of the paper.

2. Format Manuscripts (including captions, synonymies, literature cited, and tables) should be typed double-spaced on standard letter-size paper with a 4$\mathrm{cm}$ (I") margin on all sides. Three photocopy copies should be submitted to the Head of Publications; the original should be retained by the author. The submission should include a separate sheet giving the names and affiliations of the author(s), the title of the publication, the series if applicable, the number of typed pages, the number of tables, and the number of plates and figures. Manuscripts should normally be organized in the following order: contents, abstract, introduction, materials and methods, results, discussion, conclusions, summary (if manuscript is long), acknowledgements, appendices, and literature cited. Authors are encouraged to include foreign-language translations of the summary, if appropriate. Main headings should be centred; sublreadings should be left-justified to the text margin. The first line of the first paragraph in each new section should not be indented. A single space only should be left between sentences. Material intended to be typeset as italic must be provided as italic, not as underlined roman type. Literature citations in the text should be in one of the following forms: "Jones (1994)" or "(Jones, 1994)" or "(Smith, 1990:71-79, fig. 17)."

3. Standard Sources The primary authority on questions of format and style is the Guide to Authors and Editors, available from ROM Publications. For mat- ters not covered in the guide, consult the CBE Style Manual. Other standard sources are as follows: for English spelling, The Concise Oxford Dictionary; for Canadian place names and coordinates, Canada Gazetteer Atlas; for the spelling of geographic names, The Times Atlas of the World.

4. Abstract All papers must be preceded by a short, factual abstract, about one per cent of the text in length. The abstract may be followed by four to six key words in parentheses.

5. Taxonomy The name of a taxon should be given in full in headings, at the beginnings of paragraphs, and at its first occurrence in the text. Give the authority and date, if appropriate, with the first mention of each taxon, but not thereafter. Taxonomic papers, particularly synonymies, should follow the layout in the Guide to Authors and Editors. International Codes of Biological Nomenclature must be followed.

6. Literature Cited A complete list of references, in alphabetical order of authors, must be given at the end of the paper. When two or more works of one author are cited, they should be listed chronologically. The names of journals should not be abbreviated. For correct bibliographic form, see the Guide to Authors and Editors.

7. Tables All tables should be typed on separate sheets and numbered consecutively in arabic numerals in the order of their first mention in the text. Mark the location of each table in the margin of the text.

8. Plates, Figures, and Text-figures Illustrations may be designated according to the conventions of the author's discipline; in some disciplines grouped photographs of scientific subject matter are commonly termed Plates, while line drawings and locality and other illustrations that occupy a full page or less are Text-figures. Usage must be consistent throughout the paper. A full-page illustration with its caption should be sized to fit an area of $17.3 \times 22.75 \mathrm{~cm}$ $\left(6.8^{\prime \prime} \times 9^{\prime \prime}\right)$ for a Contribution; for Occasional Papers, the area is $14.1 \times 21.2 \mathrm{~cm}\left(5.5^{\prime \prime} \times 8.3^{\prime \prime}\right)$. If captions are lengthy, they may be placed on the facing page. A scale or magnification factor should be included. Authors are reminded that when illustrations are reduced, magnification factors will change, and that they are responsible for the conversion. For details, see the Guide to Authors and Editors. 
o 


\section{ROYAL ONTARIO MUSEUM LIFE SCIENCES CONTRIBUTIONS}

Life Sciences Contributions are a numbered series of scientific publications of varied subject matter. Most recent contributions include the following:

157 Classification and Evolution of the Oraseminae in the Old World, Including Revisions of Two Closely Related Genera of Eucharitinae (Hymenoptera: Eucharitidae) John Michael iteraty 1994, 184 pp., ill., \$24.95 ISBN 0-88854-412-X

156 Conodonts of the Lower Border Group and Equivalent Strata (Lower Carboniferous) in Northern Cumbria and the Scottish Borders, U.K. Mark A. Purnell 1992, 80 pp., ill., \$19.95 ISBN 0-88854-405-7

155 Revision of the World Species of Spalangiopelta (Hymenoptera: Chalcidoidea: Pteromalidae: Ceinae) D. Christopher Darling 1991, 48 pp., ill., \$11.00 ISBN 0-88854-395-6

154 Shallow-Water Hydroids of Bermuda: The Thecatae, Exclusive of Plumularioidea Dale R. Calder 1991, 144 pp., ill., $\$ 24.50$ ISBN 0-88854-354-9

153 Silurian Trilobites from the Northern Yukon Territory Rolf Ludvigsen and Ronald P. Tripp 1990, 64 pp., ill., \$12.95 ISBN 0-88854-349-2

152 The Type Species of the Ordovician Trilobite Genus Isotelus: I. gigas Dekay, 1824 David M. Rudkin and Ronald P. Tripp 1989, 24 pp., ill., \$10.25 ISBN 0-88854-345-X

151 The Structure of the Call Note System of the WarblingVireo Daryl Howes-Jones and Jon C. Barlow 1988, 40 pp., ill., $\$ 11.00$ ISBN 0-88854-343-3

150 Late Cretaceous-Early Tertiary Dinoflagellates and Acritarchs from the Kashi Area, Tarim Basin, Xinjiang Province, China Mao Shaozhi and Geoffrey Norris 1988, 100 pp., ill., $\$ 25.00$ ISBN ()-88854-334-4
149 Occurrence of the Cladid Inadunate Crinoid Thalamocrinus in the Silurian (Wenlockian) of New York and Ontario George C. McIntosh and Carlton E. Brett 1988, 20 pp., ill., $\$ 7.75$

ISBN 0-88854-342-5

148 Shallow-Water Hydroids of Bermuda:

The Athecatae

Dale R. Calder

1988, 112 pp., ill., $\$ 24.50$

ISBN 0-88854-339-5

147 Biostratigraphy and Palaeontology of the Scollard Formation, Late Cretaceous and Paleocene of Alberta

Loris S. Russell

1987, 23 pp., ill., $\$ 7.00$

ISBN 0-88854-338-7

146 Stipatocrinus, a New and Unusual Camerate Crinoid from the Lower Silurian of Western New York

James D. Eckert and Carlton E. Brett 1987, 17 pp., ill., $\$ 6.00$

ISBN 0-88854-336-0

145 An Annotated Checklist of the Fishes of the Chagos Archipelago, Central Indian Ocean Richard Winterbottom, Alan R. Emery, and Erling Holm 1987, 240 pp., ill., $\$ 50.00$ ISBN 0-88854-329-8

144 Revision of the Caddisfly Genus Psilotreta (Trichoptera: Odontoceridae) Charles R. Parker and Glenn B. Wiggins 1987, 55 pp., ill., $\$ 12.00$ ISBN 0-88854-332-8

143 Phylogeny, Speciation, and Palaeoecology of the Early Carboniferous (Mississippian) Conodont Genus Mestognathus Peter H. von Bitter, Charles A. Sandberg, and Michael J. Orchard 1986, 115 pp., ill., $\$ 25.00$ ISBN 0-88854-319-0

\section{A catalogue of $\mathrm{ROM}$ publications in print is} available from

University of Toronto Press

10 St. Mary Street, Suite 700

Toronto, Ontario M4Y 2W8

Canada

Tel. (416) 978-2229 Fax (416) 978-4738 